ROCZNIKI HUMANISTYCZNE

Volume 66, issue $1-2018$

SELECTED PAPERS IN ENGLISH

DOI: http://dx.doi.org/10.18290/rh.2018.66.1-3e

\title{
LUIGI MARINELLI
}

\section{POLISH DANTISM: BETWEEN EPIC AND ETHICS}

Considerate la vostra semenza: fatti non foste a viver come bruti, ma per seguir virtute e canoscenza.

Dante, Inferno XXVI, 118-120

Call to mind from whence ye sprang:

'Ye were not form'd to live the life of brutes,

'But virtue to pursue and knowledge high.'

Dante, Inferno XXVI, 118-120

(transl. H.F. Cary)

In memory of Riccardo Picchio

Although it remains outside the "eastern boundaries of the world of Dante," Polish literary culture is perhaps, among other Slavic literatures, the

LUIGI MARINELLI-professor ordinarius, since 1994 Chair Professor of the Department of Polish Language and Literature at La Sapienza University in Rome, international member of the Polish Academy of Sciences (PAN) and the Polish Academy of Learning (PAU), member of the Editorial Board of Pamiętnik Literacki and of the boards of a number of major Polish literary periodicals; address for correspondence: e-mail: luigi.marinelli@uniroma1.it

The Polish version of this article was published in Roczniki Humanistyczne 60, issue 1 (2012).

${ }^{1}$ See R. Picchio, M. Simonelli, "I confini orientali del mondo di Dante," in: Dante i slavenski svijet/Dante e il mondo slavo, Atti del Convegno internazionale, Dubrovnik, 26-29 X 1981, ed. Frano Čale, vol. 1 (Zagreb: Jugoslavenska Akademija Znanosti i Umjetnosti 1984), 13-29; as was noted by the married couple of Italian medievalists, it is precisely the absence of the fragmented and conflicting Polish territory on the "model Christian map of Europe" that justifies "the assumption that Dante did not deal with Poland, because in this part of the Latin Catholic world - although very important - there were no legal conditions that could be defined by referring to the structure of unicus principatus (territorial unity) to which every human authority should refer. This confirms the impression that Dante, when setting the boundaries of the European world, which he commented on and imitated in his works, was not guided by the boundaries 
one in which Dantism has played the most ample and, at the same time, the most profound role. Without a doubt, although Dantism is but an aspect of the (linguistic, cultural, artistic, and literary) macro-phenomenon of "Italianism," 2 at the same time, at least since the age of Romanticism, ${ }^{3}$ Polish literary culture has not been able to do without it and has treated it as "its own." From Forefathers' Eve by Mickiewicz to Ferdydurke by Gombrowicz; from the Non-Divine Comedy by Krasiński and The Spirit King by Słowacki ${ }^{5}$ to the processions of the dead, a favorite theme of Symbolist painters and poets (especially the most renowned author, Bolesław Leśmian ${ }^{6}$ ) and the "theatre of death" of Tadeusz Kantor; from the multiplication of Polish "Francescas" in the latter half of the $19^{\text {th }}$ century (Bełcikowski, Konopnicka, Faleński, Miriam-Przesmycki, Zawistowska) to the descent into the netherworld in The

of Latin Catholicism as such, nor by the policy of the Holy Roman Church (especially: Purgatory VII, Paradise XIX and De vulgari eloquentia VIII)," quotation on p. 26-27.

${ }^{2}$ It would be pointless and irrelevant to recall here the endless bibliography of Polish Italianism (a longstanding phenomenon of a macro-cultural nature, mainly concerning language, but also art, customs, gastronomy, fashion and, of course, Polish literature). From the point of view of literary comparative studies, however, I will at least signal the most recent extensive, but in some respects also controversial, synthesis by Olga Płaszewska, Przestrzenie komparatystyki-italianizm (Kraków: Wydawnictwo UJ, 2010). The author, omitting a few references, does not devote too much attention to the vast problem of Dantism in Poland.

${ }^{3}$ On the question of Dante's presence in Polish Pre-Romantic culture and literature see Andrzej Litwornia, "Dante, któż się odważy tlumaczyć.” Studia o recepcji Dantego w Polsce (Warszawa: Zakład Narodowy im. Ossolińskich, 2005).

${ }^{4}$ Dante's impact on this poetic drama, essential for the understanding of the philosophical and literary phenomenon of Polish Messianism, was summed up aptly by Czesław Miłosz in the following words: “At the basis of Forefathers' Eve is the fact of communion between the living and the dead, i.e. intercession. The dead ask the living for help (the Forefathers' Eve rite), the living rescue the living by prayers (Ewa, Father Piotr), the dead protect the living ("the earthly mothers of your merit"). The system is threefold: Heaven, triumphant Church, Good, Inferno, the reprobate, Evil. The battle between Evil and Good is unequal, and although sometimes, with the help of good spirits, humans save themselves from destruction, Evil is strong, Good is weak, although it will ultimately triumph" (see in: IDEM, Ziemia Ulro (Paryż: Instytut Literacki, 1980), 103).

${ }^{5}$ Two Italian essays on the presence of Dantism in the works by two other Polish Romantic bards are worth mentioning here: Bruno MerigGi, "Motywy dantejskie w 'Królu Duchu' Słowackiego," in: Mélanges de littérature comparée et de philologie offerts à Mieczystaw Brahmer (Warszawa: Państwowe Wydawnictwo Naukowe, 1967), 349-356 and P. MARCHESANI, "Per una rilettura della 'Non Divina Commedia' di Zygmunt Krasiński, poeta romantico polacco," in: Dantismo Russo e cornice europea. Atti del Convegno di Alghero-Gressoney (1987), introduction Eridano Bazzarelli, v. 1 (Firenze: Olschki, 1989), 47-53.

${ }^{6}$ On the presence of a procession of spirits and their probable Dantesque origin (via the nearly parallel translation by Porębowicz) in Leśmian's poetry (Legendy tęsknoty, Postacie, Spowiedź) see convincing observations by Wojciech Owczarski, Miejsca wspólne, miejsca własne. O wyobraźni Leśmiana, Schulza i Kantora (Gdańsk: Słowo/obraz terytoria, 2006), 200-202. 
Sanatorium Under the Sign of the Hourglass and the spectacular "last act of the divine comedy" in The Comet, a short story by Bruno Schulz; from the poetry and memoirs of the Gulag by Aleksander Wat, ${ }^{8}$ Gustaw Herling Grudziński and Stanisław Vincenz to Eliot's references to the great European and Christian tradition in Herbert and-in its hermetic and symbolist version-in Miłosz, as well as the neo-avant-garde of Grochowiak' from the grotesque and desperate pessimism of Tadeusz Konwicki's novels (starting with The Little Apocalypse ${ }^{10}$ ) to the entire epopee of Warsaw (before, during and after World War Two) through The City of Anguish by Jerzy Pilch (2004), and possibly the recent grand narratives dedicated to the nonexistent world of peasants, ${ }^{11}$ etc. many outstanding texts of Polish literature refer to, even though only cursorily and indirectly, Dante and The Divine Comedy. We must not leave aside numerous minor "Italianized" texts and all those

\footnotetext{
${ }^{7}$ Bruno Schulz, Kometa, in: IDEM, Proza (Kraków: Wydawnictwo Literackie, 1973²), 320. The subject of the "Last Judgement," and primarily of the interpretation of one of Schulz's bookplates for Stanisław Weingarten, are addressed in Władysław Panas's memorable text: Bruno od Mesjasza (Lublin: Wydawnictwo UMCS, 2001), esp. 7-70 (reproduction of the bookplate can be found on p. 204). In the "canonical" catalogue Bruno Schulz 1892-1942. Rysunki i archiwalia ze zbiorów Muzeum Literatury im. Adama Mickiewicza w Warszawie, ed. Wojciech Chmurzyński, vol. II: Katalog - Pamiętnik Wystawy "Bruno Schulz. Ad Memoriam" (Warszawa: Muzeum Literatury im. Adama Mickiewicza, 1995), the bookplate for Weingarten is assigned no. 451, p. 294. On the dual inspiration by Schulz and Dante in the oeuvre of Tomasz Różycki, one of the most eminent Polish contemporary poets, see also: Magdalena RABIZO-BIREK, "Szlakiem Dantego i Schulza," Kresy. Kwartalnik Literacki 63 (2005): 77-91.

${ }^{8}$ In his critical monograph Aleksander Wat. Life and Art of an Iconoclast (New Haven and London, 1996, 230-233), Tomas Venclova refers to the Dantesque inspiration for Wat's poem Podróz [Journey]; the biographical background of the poem was the author's transfer from one prison to another in Kiev in 1940. Dante's presence in Wat's poetry may be more dispersed, however, and awaits further investigation.

${ }^{9}$ The Dantism of Stanisław Grochowiak is addressed by Małgorzata Łukaszuk-Piekara in “Wizje splatane z historiami”. Autobiografia liryczna poety (Lublin: Redakacja Wydawnictw KUL, 2000), 405-406.

${ }^{10}$ On which Milan Kundera wrote as follows: "Konwicki like a Polish Dante leads us through the contemporary Inferno, where we meet the living and the dead", quoted after: Stanisław BEREŚ, "Konwicki-polski Dante wśród popiołów," Dziennik 13.01.2009, accessible online: <http://kultura. dziennik.pl/ksiazki/artykuly/86110,konwicki-polski-dante-wsrod-popiolow.html> .

${ }^{11}$ Zygmunt Ziątek sees a general reference to Dante especially in quasi-autobiographical texts by Adam Bień and the summa novel Kamień na kamieniu by Wiesław Myśliwski, in the motif of the incessant exchange and dialogue between the living and the dead in the last texts of the Polish peasant current ("Chłopska przygoda z historią i literaturą. Adam Bień i inni," in: Dwudziestowieczność, edited collection ed. Mieczysław Dąbrowski and Tomasz Wójcik (Warszawa: Wydano nakł. Wydziału Polonistyki Uniwersytetu Warszawskiego, 2004), 185).
} 
tens or hundreds set in Italy (in Ravenna, Florence, Rome...), and which in diverse ways refer to Dante and his oeuvre. ${ }^{12}$

In everyday Polish, the phrase "Dantesque scenes" (sceny dantejskie) is equivalent to the expressions: "terrifying scenes," "scary visions," often referring to a thicket of people, which says a lot about which of the three parts of the poem was the most succesful and most important for the collective memory and imagination of Poles; it did not differ from the extensive, centuries-long European tradition. ${ }^{13}$ The extra-literary motivation, however, is so much more extensive!

In one of the volumes of poetry known and loved in the interwar period, devoted to such topics as impossible love, death, loneliness and the tragedy of existence, its author-Jan Lechoń-dedicated as many as two out of twenty poems to Dante. In the Meeting poem, the poetic persona sees Dante in a dream, on a bridge in Ravenna. The last two stanzas are a record of an oneiric dialogue, conducted across the many centuries and thousands of kilometers separating the poets: the living and the dead one:

It is you, it's you, my master! Why are you so pale And why does this strange anxiety glow within you?

I've come to beg you for the secret of your face.

I don't know anything. I got lost. And I ask your advice.

He said it, or the moon said it, or the water said it,

I fell down, hiding my head with both hands:

"There is no heaven and no earth, no abyss, no hell,

There is only Beatrice. And now she is not."14

The last, very well known verse of Lechon's poem, was to become the title of one of the most eminent historical novels by Teodor Parnicki, set in the

\footnotetext{
${ }^{12}$ I am referring to literary texts of great genetic, qualitative and goal-oriented diversity, an example of which, among countless others, is Zdzisław Morawski's three short stories about ancient Ravenna, collected under the title $Z$ Rawenny [From Ravenna] (Kraków: Krakowska Spółka Wydawnicza, 1921), published to commemorate the $600^{\text {th }}$ anniversary of Dante's death.

${ }^{13}$ It is no coincidence, as stressed by a young Italian scholar, that partial Polish translations of The Divine Comedy focus mainly on a few cantos of Inferno (I, III, V, XXXIII), to which canto V of Purgatory is often added, since "it can be seen as a manifestation of ultimate patriotism" (Andrea Fernando De CARLo, Dante nella Polonia del XIX secolo. Le traduzioni della Divina Commedia a confronto: Kraszewski, Korsak, Stanisławski, Porębowicz, tesi di dottorato in Scienze letterarie, filologiche, linguistiche e glottodidattiche, (Università del Salento, Lecce, 2008/2009), 37) [doctoral dissertation, typescript].

${ }^{14}$ Quoted after Jan LECHOŃ, Srebrne i czarne [1924²], (Warszawa: Wydawnictwo Jakuba Mortkowicza, MCMXXVIII), 7-8; the second "Dantesque" poem from the collection, $\mathrm{Na}$ "Boskiej Komedii" dedykacja, is on p. 11.
} 
early $14^{\text {th }}$ century: Tylko Beatrycze [Only Beatrice]. ${ }^{15}$ Yet this Beatrice, who "is" and "now she is not," might in fact be the key to reading the entire unusual history of Polish Dantism. Not only because the widespread "Dantomania" is offset, understandably, by "Dantophobia" (with the sublime and antiphrastic example of Witold Gombrowicz's book O Dantem [On Dante], ${ }^{16}$ to which I will refer later on), but primarily because despite the enormous impact of Dante's oeuvre - actual and imaginary, read or known by hearsayhas had on the last two centuries of the development of this literature and its transformation, we still await a genuine synthesis of this cultural and literary macro-phenomenon of Polish Dantism. Until recently, critical studies dedicated to its history were an exception rather than a rule and, except for a few cases like the old and precious bibliography by Preisner ${ }^{17}$ or Kalikst Morawski's outdated monograph ${ }^{18}$ one cannot claim that these texts were of exceptional quality. The obvious reversal of this trend has been influenced by recently published important studies and translations. ${ }^{19}$ A partial stagnation was undoubtedly caused by the statements of pseudo-Marxists representing the regime's critics for its idiosyncratic attitude towards "religious" literature

\footnotetext{
${ }^{15}$ See Teodor PARnicki, Tylko Beatrycze [Only Beatrice], (Warszawa: Pax, 1962). Written at the time of the Mexican emigration, much earlier than The Name of the Rose by Umberto Eco, Parnicki's novel is a fascinating story about intrigue, love secrets, revenge, the promiscuity of the Cistercians, peasant uprisings, burnings at the stake, heresies, etc. Set in Europe at the beginning of the $14^{\text {th }}$ century, it focuses especially on travels around Europe and beyond, between the Polish monastery (where the friars discuss and quote the first two parts of Dante's Comedy) and the Holy See, and on the constant search for identity by the main character, Stanisław Polak, also known as Deacon Jan, who suffers from "a bastard son" complex, for whom the Czech queen Richeza is the equivalent of the mysterious "Beatrice." On the subject of this unusual novel and its Dantesque connections, see Alina KreISBERG, “'Soltanto Beatrice' di Teodor Parnicki, una eco moderna della 'Commedia dantesca'," in: Dante i slavenski svijet, v. 1, 309-316.

${ }^{16}$ See Witold Gombrowicz, $O$ Dantem, a bilingual, Polish-French edition (Lausanne: L'Herne, 1968).

${ }^{17}$ See Walerian PreISNER, Dante i jego dzieła w Polsce. Bibliografia krytyczna $z$ historycznym wstępem, (Toruń: Państwowe Wydawnictwo Naukowe, 1957).

${ }^{18}$ See Kalikst MoRAwSKI, Dante Alighieri, (Warszawa: PAX, 1961); we should also point to an article by this author titled "Dante w Polsce", Życie i Myśl no. 3-4 (1965), 142-156 and an extensive introduction to the (partial) edition of The Divine Comedy in the canonical translation by Edward Porębowicz, repeatedly reprinted in the Biblioteka Narodowa series by Ossolineum Publishers in Wrocław, See Introduction, in: Dante Alighieri, Boska Komedia (Wrocław: Zakład Narodowy im. Ossolińskich, 1977), III-CXVIII.

${ }^{19}$ In this sense, apart from the aforementioned book by Andrzej Litwornia, Agnieszka Kuciak's book on Dante's reception during Polish Romanticism (Dante romantyków. Recepcja "Boskiej Komedii” u Mickiewicza, Stowackiego, Krasińskiego i Norwida (Poznań: Wydawnictwo Naukowe UAM, 2003)) is just the first chapter (principal and also the most frequently studied so far) of a far more extensive work on "Dante and Dantism in Polish literature," which is yet to be written.
} 
perversely gave way to ultra-Catholic "Dantology" in post-totalitarian Poland $^{20}$ ). It is true that after World War Two, when in communist Poland one could only witness a debate on a greater or lesser progressiveness of Dante's oeuvre $^{21}$ (and that of many other great writers of canonical texts) - with rare exceptions $^{22}$ - major critical texts concerning Alighieri came first of all from émigré writers and critics, not necessarily religiously-minded. Naturally, "the condition we call exile" (to apply Brodsky's term ${ }^{23}$ ) proved exceptionally fruitful for Dantology, or even for more personal readings of Dante. We can therefore agree with the statement of an outstanding contemporary Polish Italianist that fortunately "Dante's current presence in Poland is not limited

\footnotetext{
${ }^{20}$ See e.g. the introduction by Paweł Lisicki titled Dziedzictwo Dantego in the most recent entire translation of The Divine Comedy translation of The Divine Comedy in hendecasyllable terza rima, by the Italian Studies scholar and poet Agnieszka Kuciak: See Dante AlighIERI, Boska Komedia, transl. Agnieszka Kuciak (Poznań: Fundacja św. Benedykta, 2006), 5-35. This introduction, through its journalistic and apologetic style (it even justifies the fact that Dante casts so many popes into hell...), certainly does not pay due tribute to this latest and excellent translation of The Divine Comedy and it is doubtful that it will have the intended effect of drawing the attention of a wider audience to this translation-also because of the editorial context: The Divine Comedy came out in the Biblioteka Christianitas series by Fundacja Św. Benedykta in Poznań, which publishes, apart from theological, mystical and apologetic texts, works mostly written by saints and doctors of the Catholic Church. Of course, there are also completely different articles of a theological and literary character, such as the text by Wacław Świerzawski on the Marian themes in The Divine Comedy: "Wątek mariologiczny w 'Boskiej Komedii’ Dantego," Częstochowskie Studia Teologiczne v. 19/20 (1991-92) (1993): 59-76.

${ }^{21}$ See Piotr SALwA, "Dante e la critica polacca degli ultimi anni," in: Dante i slavenski svijet, v. II, 589-596.

${ }^{22}$ By way of example, it is enough to mention that in the years 1963-1982 even the most prestigious and in many respects "open-minded" Polish literary periodical, the quarterly Pamiętnik Literacki of the Institute of Literary Studies (IBL) of the Polish Academy of Sciences (PAN), did not publish anything about Dante save a translation of a short article by Yuri Lotman on Ulysses: “The Journey of Ulysses in Dante's Divine Comedy," Pamiętnik Literacki No. 4 (1980): 127-138. We should also bear in mind that at this time Dante studies in Poland, having resource solely to the first, pioneering $19^{\text {th }}$-century scholarship (Kłaczko, Kraszewski, Porębowicz), was perforce based on texts in other languages and on translations by foreign authors, especially: Michele BARBI, Dante. Vita, opere e fortuna (Firenze: G.C. Sansoni, 1933!), Polish transl. Jadwiga Gałuszka under the title Dante (Warszawa: Państwowy Instytut Wydawniczy, 1965), and a 1964 study by Olof Lagercrantz, Od piekiet do raju. Dante i Boska Komedia (Warszawa: Państwowy Instytut Wydawniczy, 1970); for a complete bibliography from the period since the "political thaw" in Poland till the introduction of martial law see: M. RozPĘDOwsKA, Dante w Polsce (1957-1981) (Warszawa, 1983).

${ }^{23}$ The Italian translation of the 1987 essay The Condition We Call Exile [La condizione che chiamiamo esilio] is included in: Iosif BrodskiJ, Profilo di Clio, ed. Arturo Cattaneo (Milano: Adelphi, 2003), 41-56; naturally, in the essay the name of Dante recurs next to Ovid and Joyce, or those who belong to the "linage" of an exiled writer (p. 47).
} 
to classical academic reflection, which is not too extensive in the first place." 24 There is a clear disproportion between Dantism and Dantology; Polish literary and academic culture, at times influenced by mutual mistrust, assigned to them very different and distant places and periods.

Besides, if we want to consider the question from a theoretical perspective, we must add that the Dante who "is" and at the same time "is not" in Poland, may be interpreted moreover as an allegory of the general situation of so-called "minor" literatures (Polish literature included). These literatures, although they believe to have expressed their own "Dante," find it hard to show it and are usually marginalized, if not excluded, within the (European, Western, global) canons, far more capacious than those delineated for them by the "higher," dominant contexts they belong to and confront of necessity. ${ }^{25}$ In vain have some eminent writers of a "minor" literature (such as Gombrowicz, Vincenz and Miłosz in Polish literature) opposed this kind of market (and geopolitical!) logic which represents the groundwork for the above hierarchy of literatures. With his signature insightfulness, Gombrowicz in the first fragments of this greatest work, Dziennik [Diary], refers to Dante, censuring the masochistic inferiority complex and mania of comparisons often and eagerly adopted by Polish critics and writers. The reference point for Gombrowicz was the judgement in one article by Jan Lechon', who was at that time an emigrant who experienced-like others before and after hima language barrier and thus the (false) problem of untranslatability, which eventually led him to believe that foreign readers cannot grasp "the level of our poets, equal to the greatest of the world, to grow certain that this poetry is of the same metal, and of the same supreme quality as Dante's, Racine's and Shakespeare's." ${ }^{26}$ It is worthwhile following Gombrowicz's entire reasoning to be certain that his alleged "anti-Dantism" - which in connection with the

\footnotetext{
${ }^{24}$ Piotr SALwA, “Dante in Polonia: una presenza viva?," Dante Studies CXIX (2001): 194.

${ }^{25}$ I wrote about it referring precisely to Gombrowicz, the author of a short book $O$ Dantem, who, in others' opinions, also "remains till now the major Polish author addressing the question of the canon" (Piotr WiLCZEK, "Kanon tradycji uniwersalnej a zadania narodowej historii literatury," in: Polonistyka w przebudowie. Zjazd Polonistów Kraków 22-25 września 2004, ed. Małgorzata Czermińska et al., v. II (Kraków: Universitas, 2005), 118) in: Luigi MaRINELLI, "Kanony i kanonady. O kanonie 'europejskim' a literaturach 'mniejszych' (na przykładzie literatury polskiej)," in collected essays: Europejski kanon literacki. Dylematy XXI wieku, ed. Elżbieta Wichrowska (Warszawa: Wydawnictwo UW, 2012), 90-106.

${ }^{26}$ Witold Gombrowicz, Dziennik (1953-1958) (Paryż: Gallimard, 1982²), 12; Lechoń's article which Gombrowicz references in this excerpt was also published in 1953 in Wiadomości, a Polish émigré weekly in London, titled Literatura polska a literatura w Polsce [Polish literature vs. literature in Poland].
} 
book $O$ Dantem literally outraged Giuseppe Ungaretti ${ }^{27}$-is a provocation, yet expresses a sentiment not only fundamentally confrontational about the writer's own value, language and literature, aiming at full inclusion into the grand European tradition of debate on languages, their origins and dignity, of which Dante, thanks to De vulgari eloquentia and his other works in the vernacular, was one of the founding fathers. Gombrowicz observes:

Made of the same metal? I don't think Lechon was very successful. Because the matter from which our literature is made is different.

To compare Mickiewicz with Dante or Shakespeare is to compare fruit with jam, natural product with processed product, meadow, field and village with a cathedral or city, idyllic soul with urban soul embedded in people, not in nature, charged with knowledge about the world of mankind. Was Mickiewicz more minor than Dante? If we are to give up on these measurements, let's say that he looked at the world from the gentle Polish hills, while Dante was elevated to the top of a huge mountain (made up of people), from which other perspectives open up. Dante, not being perhaps "bigger," was positioned higher: that's why he dominates. ${ }^{28}$

Here, Gombrowicz's problem also seems to be what he himself calls "Form," created for individuals and groups of social and cultural stereotypes and canons, which inevitably lead to inane, unnecessary and at times tragic confrontations (between individuals and groups), which naturally do not help them to leave "a dark wood" of "immaturity." 29 Within this perspective, one might reread a famous quote from Dante, on page two of Gombrowicz's masterpiece Ferdydurke: "In the middle of the journey of my life I found myself astray in a dark wood. The wood was, worse of all, green." 30

Just like Gombrowicz, the Mickiewicz-Dante parallelism was repeatedly addressed by another major writer and critic of Polish emigration, Stanisław Vincenz. ${ }^{31} \mathrm{He}$, too, tried to retain an adequate sense of perspective and although

\footnotetext{
${ }^{27}$ See Giuseppe Ungaretti, "Lettre à Dominique de Roux," Cahier de l'Herne No. 14 (1971): 418.

${ }^{28}$ W. Gombrowicz, Dziennik, 13.

${ }^{29}$ I will mention only Francesco M. Cataluccio, Niedojrzałość. Choroba naszych czasów, (Kraków: Znak, 2006) out of the extensive bibliography dedicated to the issue of "form" and "immaturity" in Gombrowicz.

${ }^{30}$ Witold Gombrowicz, Ferdydurke, ed. Jan Błoński (Kraków: Wydawnictwo Literackie, 1986), 6.

${ }^{31}$ It is not surprising that references to Dante and Mickiewicz often appear in texts by Jewish authors, both in Italian and Polish literature before the Holocaust, and even more so after the Shoah. As Laura Quercioli Mincer accurately pointed out, these references signal recognition of one's own identity, perfectly understandable for these authors, because it was "classical art and masterpieces of national literature (especially the works of Dante and Mickiewicz) that restored
} 
he wanted to "discover some affinity in the spiritual organization" 32 in the two poets' shared soteriological pursuit of "capturing a unity, ${ }^{, 33}$ he did not mistake the "epic of the entire humanity," i.e. Alighieri's Christian medieval universalism, with what could be called a national-romantic universalism of the Polish Romantic bard, expressed through his Messianism (which was, let us stress, a utopian and millenarian Messianism, in a way permeated with the spirit of universalism, unlike the wartime, racial and colonial nationalisms of the following century, which is concisely and aptly summarized by the wellknown motto: "For our freedom and yours" 34 ).

Despite all the caution of writer-critics, the impression remains that Dantism (as well as Polish Shakespeareanism, to mention only two figures of the great European tradition, which are most often linked because of their magnitude, exceeding the needs of the system, as well as of the local cultural and literary market), is a strong argument in favor of "the anxiety of influence," which Harold Bloom sees as one of the fundamental elements of the "Western canon." The typology and gravity of Dantism in the Polish cultural and literary system is a kind of litmus test of both its obvious affiliation to European culture and of the "minority" space, which is, however, attributed to it within the European polysystem. In virtue of some "Bartoli's law" of the creation of literary polisystems (and/or canons), "minor" literatures, as marginal or rather marginalized, would of their own "nature" tend towards the center

the sense of cultural continuity by belonging to a community better than the one that had produced assassins and their assistants. Finding such a relationship meant that the survivors could at least to some extent overcome the experience of the Shoah"; it is significant, Mincer continues, that Stanisław Vincenz: "In Polish literature, was one of the few who simply and quite plainly felt closest to the Jews [....], and in developing his vision of soothing memory, he refers to Dante [and Mickiewicz]" (Ojczyzny ocalonych. Powojenna literatura żydowska w Polsce $i$ we Wtoszech (Lublin: Wydawnictwo UMCS, 2009), p. 19 and 211).

${ }^{32}$ Stanisław Vincenz, Dante $i$ Mickiewicz, in: IDEM, Atlantyda. Pisma rozproszone z lat II wojny światowej, ed. Jerzy Snopek (Warszawa: Świat Literacki, 1994), 58. All of the Dantesque texts by Vincenz, regrettably never gathered in a single volume and still scattered among different collections of his criticism, have recently been analyzed and graciously commented on in Tadeusz Sucharski’s book, Polskie poszukiwania ,innej” Rosji. O nurcie rosyjskim w literaturze Drugiej Emigracji (Gdańsk: Słowo/obraz terytoria, 2008), esp. 171-184 and the footnotes, which we will come back to on a number of occasions.

${ }^{33}$ Stanisław Vincenz, Dantyzm w Polsce, in: IDEM, Po stronie pamięci. Wybór esejów (Paryż: Instytut Literacki, 1965), 116.

${ }^{34}$ It is hardly a coincidence that the motto, attributed to Joachim Lelewel, the master of the entire generation of Polish patriots and the author of Geographie du Moyen Age (Bruxelles: Pilliet, 1852-1857), first appeared in a bilingual Polish-Russian version on both sides of a banner carried on 31 January 1831 during a rally held to commemorate the Decembrists murdered or exiled by the tsarist regime after the Russian insurgence of 1825 . 
than the "major" ones. Their peripheral character, precisely due to the minor impact of "the anxiety of influence" or rather, in Bloom's terms, due to the fact that they can express with less effort the figures who, when fighting, liberate themselves at least from "the anxiety of influence," 35 is responsible for the fact that they can far easier be transformed into a "new center." 36 This could account for the the paradox of Dante studies: in spite of the fact that Dante is a lively presence in Polish culture, Dantology is not as widespread in Poland as it is in Russia where, according to Osip Mandelstam, "poetry developed as if Dante had never existed." ${ }^{37}$ I must observe, then, that it was this "anxiety of influence" that Joseph Brodsky devoted the first pages of his essay-review of Montale titled $W$ cieniu Dantego, where the presence of "as if he had never existed" seems really significant:

The spirits of the great can be particularly noticeable in poetry, because their words are less changeable than the thoughts they express. That is why every poet puts a lot of effort into battling those shadows whose hot or cold breath he feels on his neck-either by himself or thanks to the diligence of literary critics. The classics exert so much pressure that the result is sometimes a real paralysis of language ... Natural ignorance or even pretended naivety seems a blessing, because it allows man to celebrate all specters as non-existent [italics-L.M.] and to "sing" (preferably in vers libre) only with a sense of one's own physical presence on stage ... If the poet lives long enough, he learns to deal with drought periods ... using them for his own purposes ... It is paradoxical that an artist is richer when he is less indebted. ${ }^{38}$

This "disregard of Dante" which Mandelstam ascribes to Russian poetry and readers, ${ }^{39}$ may be the starting point for my arguable, yet hopefully clear,

\footnotetext{
${ }^{35}$ Harold Bloom, The Western Canon: The Books and School of the Ages (New York: Harcourt Brace \& Company, 1994), the quote from the Italian translation: Il canone occidentale. I Libri e le Scuole delle Età, a cura di Francesco Saba Sardi (Milano: Bompiani, 2000²), 8.

${ }^{36}$ On the (dynamic) relations between the center and the peripheries in terms of the polisystems theory of Even-Zohar see Rakefet SHEFFY, "The Concept of Canonicity in Polisystem Theory," Poetics Today 11 (1990): 511-522. Fundamental for this issue is Itamar Even-Zohar's article "The Position of Translated Literature within the Literary Polysystem," Papers on Poetics and Semiotics 8 (1978): 21-27.

${ }^{37}$ Osip Mandel'štam, Razgovor o Dante (1932), quoted after: Michele ColuCCI, Note sulla Conversazione su Dante di Mandel'štam [Remarks on the conversation about Dante with Maldestam], in: IDEM, Tra Dante e Majakovskij. Saggi di letterature comparate slavo-romanze, ed. Rita Giuliani (Rome: Carocci, 2007), 176 (my italics_L. M.).

${ }^{38}$ Josif BRoDSKI, W cieniu Dantego, transl. Krystyna Tarnowska and Andrzej Konarek, in: IDEM, "Śpiew wahadła," Zeszyty Literackie 55 (1999): 63. I will come back at the end of the text to the "Brodsky and Dante" theme, due to its comparative value for the subject of this article.

${ }^{39}$ In another fragment from a notebook with his notes from 1932 for Conversation about Dante, Mandelstam makes a more general and more profound statement: "The abysmal ignorance of Italian
} 
position. Beyond the indignation and "paradoxical necessity"-as Michele Colucci calls it ${ }^{40}$ - traceable in Mandelstam's words, one can read the RussianPolish antagonism between the lines, which in the past drew the attention of many Slavic Studies scholars as well as historians of culture and ideas. ${ }^{41}$ Let me digress for a while at this point. If the work and reflection of Mandelstam and Brodsky, two great writers of Jewish origin, ${ }^{42}$ both persecuted by the Soviet regime, belong completely to the "other Russia," often invoked in support of the diverse, not solely "despotic and docile," idea of the great reality, if it is thanks to such writers that "Russia speaks European," the Conversation about Dante - not by chance written in the 1932-1933 period! - and its idea of a "man, who, in trials and tribulations, overcomes mental instability, inevitably caused by his condition of an exile, who fights à la Pushkin to gain his dignity and social position" — may be considered a very "Polish" text. It would naturally be insane to attribute this to Mandelstam being born in Warsaw in 1891. Is it a coincidence, however, that the greatest Soviet Dante scholar, the Culture Studies expert, musicologist, and composer Igor Bełza (1904-1994), the founder and animator of Dante's Readings (Dantovskie čtenija), had Polish roots? Or that a privileged place in his extensive contribution to Dante Studies was occupied by Dante's reception in Poland $?^{45}$ First of all, due to the (actual) state of exile, the term

poets — and I mean Dante, Ariosto and Tasso — on the part of Russian readers is all the more surprising that Pushkin himself owes to the Italians the explosive and unexpected character of harmony" (Osip MANDEL'ŠTAM, Vokrug "Razgovora o Dante," in: IDEM, Sobranie sočinenij v četyrech tomach, ed. Ėmilija Sergeev, vol. 3: Stichi i proza 1930-1937 (Moskva: ART-Biznes-Centr, 1994), 400).

${ }^{40}$ Michele Colucci, Note sulla Conversazione, 176.

${ }^{41}$ For more on this see my book: Luigi MARINELLI, Tra Oriente europeo e Occidente Slavo. Russia e Polonia (Roma: Lithos, 2008). Thanks to its critical methods, it may assist one in navigating the mare magnum of the extensive bibliography on the topic.

${ }^{42}$ On the Jewish element in Mandelstam's Conversation about Dante as "a mature ars poetica" and at the same time "the most creative transformation of his Jewish past" see Clare Cavanagh, "Poetyka żydowskości: Mandelsztam, Dante a 'zaszczytne powołanie Żyda'," Teksty Drugie No. 5 (1992): 47-62, quote from p. 49. Cavanagh demonstrates how Mandelstam recreates in his Dante an image of the "Jewish-poet" and a "pariah-poet", outlined in Czwarta proza, corresponding to this self-creation in Zgietk czasu. Cavanagh basically agrees with Yuri Levin, see “Zametki k Razgovoru o Dante O. Mandel'štama," International Journal of Slavic Linguistics and Poetics No. 15 (1972): 184-197, who called the figure of Dante as created by the Russian poet "an attempt at auto-description." As to other, more overt, consequences of Dantism in Jewish poets of the $20^{\text {th }}$ c. see also above, note 31 .

${ }^{43}$ See Rita GiUliani, "Quando la Russia parla europeo," Critica del testo X/1 (2007), monograph issue: Il canone europeo, 165-176.

${ }^{44}$ Michele Colucci, Note sulla Conversazione, 180.

${ }^{45}$ See Igor BEŁZA, "Niektóre rysy polskiego romantyzmu. Inspiracje dantejskie," Studia Filozoficzne No. 7 (107) (1974): 83-92. I remember that the first volume of Lektury dantejskie 
"à la Pushkin" might just as well be replaced by "à la Mickiewicz": this is a search for a live, flesh-and-blood Dante—or, as Colucci put it—Dante as a "man and intellectual with his life philosophy and world vision." ${ }^{46}$ Here is the intimate and empathic character of Mandelstam's "anti-commentary":

\begin{abstract}
Dante is a poor man of old Roman blood; internally a raznočinec, less capable of urbanity than its opposites. You need to be as blind as a bat not to see that in the entire Divine Comedy he does not know how to behave, where to stand; he does not know what to say and how to bow. ${ }^{47}$
\end{abstract}

This text resembles far too closely the fiery pages that Gombrowicz dedicated to Inferno in his Diary thirty years later which is familiar to everyone who has come into contact with the great models of $19^{\text {th }}$ and early $20^{\text {th }}$ century Polish Dantism and with what I will generally term "the necessity of Dante," as experienced by writers and intellectuals living in societies and cultures oppressed by ubiquitous, corrupt and suffocating power. This "necessity of Dante" as a guide is indicated by Stanisław Vincenz in his essay Czym może być dziś dla nas Dante (in a way responding to Eliot's What Dante Means to Me) ${ }^{48} \mathrm{He}$ would be a guide in all hard times, referring directly to being a "citizen" (cive), if "it would be ... worse for the human race if they lived outside a social state"

(Dantovskije čtenija) from 1968 began with an article by Igor Bełza Pol'skij romantizm i Dante (p. 13-32). Bełza, born in Kielce in 1904 and who died in Moscow in 1994, is commemorated by Piotr Salwa (Dante in Polonia, p. 199, note 8). The scholar quotes an autobiographical fragment of Bełza's article on Dante and the Slavs ("Dante i Słowianie," Kierunki 14 (1976): 8), where the then chairman of the Dante Commission of the USSR Academy of Sciences, "born and raised in a renowned Warsaw-based family [...], when describing his first contact with the Comedy [...] remembers walks with his mother in the most beautiful and famous park in Warsaw, during which he got acquainted with the poem in its original version, in improvised translation, even though at that time there were already various Polish versions." Aleksander Iljušin, a student of Bełza and his successor as an editor of Dantovskije čtenija and a translator of The Divine Comedy, dedicated to this exceptional man, scholar and musician, the introduction (Ot Redaktora, 5-11) to a 1995 collection. The first text of the publication was I.L. Svirida's article "Igor Fedorovič Bel'za kak istorik kul'tury," in: Dantovskie čtenija/ Letture dantesche 1995, ed. Aleksander Iljušin (Moskva: Nauka, 1996), 12-18.

${ }^{46}$ Michele ColuCCI, Note sulla Conversazione, 181.

${ }^{47}$ Osip Mandelstam, La quarta prosa (Bari: De Donato, 1967), 136.

${ }^{48}$ About this lecture, delivered by Eliot in 1950 at the Italian Institute in London and about his vision of Dante "as Eliot's Virgil, a spirit guide who has conducted him on various occasions across the frontier between the living and the dead [...] in order to "establish a relationship between the medieval inferno and modern life" we can read moreover in Stan Smith's article "Proper Frontiers: Transgression and Individual Talent," in: T. S. Eliot and the Concept of Tradition, collected edition, ed. Giovanni Cianci and Jason Harding (Cambridge: Cambridge University Press 2001), 31 (quote after: T.S. Eliot, To Criticize the Critic (London: Faber, 1965), 128.). 
(Paradise VIII 116-115). A human being, who is also a citizen, "cannot be enslaved, impartial or neutral." "It is the same "necessity" which made Mandelstam wear "on his person a pocket edition of Dante in case he was arrested," ${ }^{50}$ and which made Primo Levi remember and account hastily to his comrades, before it got too late, for the song sung by Ulysses, for which he provided an impromptu translation..$^{51}$ In all concentration camp literature, written in lagers and gulags, references to The Divine Comedy are frequent and moving: Anatol Krakowiecki will title a chapter of his Ksiażki o Kotymie [Book about Kolyma]: Lasciate ogni speranza... (Abandon all hope...); one of the most eminent Polish poets of the $20^{\text {th }}$ century, the grotesque, satirical and phantasmagorical Konstanty Ildefons Gałczyński, when an inmate in the Altengrabow Stalag, will seek intellectual solace in reading T.S. Eliot and reflecting on the affinities between Dante and Baudelaire, calling the latter in his journal "merely a chimera in the Dantesque cathedral." 52 Obviously, this is not a typically Polish phenomenon. It is enough to recall Alexander Solzhenitsyn In the First Circle, Primo Levi's Is This a Man and many other witnesses to the atrocities of the "short twentieth century." ${ }^{53}$ In the case of

\footnotetext{
${ }^{49}$ Stanisław Vincenz, Czym może być dziś dla nas Dante, in: IDEM, Eseje i szkice zebrane, selected and edited by Andrzej Vincenz, vol. 1 (Wrocław: Wirydarz, 1997), 225.

${ }^{50}$ Michele ColuCCI, Note sulla Conversazione, 179.

${ }^{51}$ See Primo Levi, Se questo è un uomo (Czy to jest czlowiek) (Torino: Einaudi, 1968), 138-145.

${ }^{52}$ See Konstanty Ildefons GAŁCZYŃSKI, Notatnik spisany $w$ dniach 18 sierpnia-18 listopada 1941 r. w Altengrabow (Warszawa: Bellona, 2009), 104: "When making a new Dante in the year 1939 one may trip and make a new Baudelaire. Yet Baudelaire is merely a chimera in a Dantesque cathedral (I owe the above meditation to the reading of T.S. Eliot's reflections on Dante)." As to Gałczyński's Dantism (which remains to be studied in depth) it may be important to re-read the great poem Niobe from 1951, where Dedication (where an echo of another extraordinary poem, List jeńca [A captive's letter], written in the Altengrabow camp on 19 March 1942) begins as follows: "W południe wieku XX/ Ten koncert ciemny jak wiatr w głazach,/ Czeladnik u Kochanowskiego,/ Złożyłem go w olsztyńskich lasach" [In the noon of the $20^{\text {th }}$ century / this concert, dark as wind among the rocks, / Kochanowski's apprentice / is laid in the forest of Olsztyn] (quoted after: Konstanty Ildefons GAŁCZYŃSKI, Dzieła w pięciu tomach, v. II: Poezje (Warszawa: Czytelnik, 1979), 425). In opposition to the Apollonian interpretation of Gałczyński's poem by the critic Andrzej Stawar, who called this incipit "an obvious paraphrase" of Dante, Aleksander Wat sums up: "To my mind, Niobe is a gloomy coming to terms with one's own error and that of one's own era, concluded by an optimistic hymn" (Aleksander WAT, Publicystyka, ed. Piotr Pietrych (Warszawa: Czytelnik, 2008), 670; a review from 1958).

${ }^{53}$ Philipe Jaccottet, a writer of Swiss-French origin, in his empathic description of the fate of Russian writers and poets who became Gulag victims or survivors (Varlam Shalamov, Mandelstam and Arjadna Efron, Marina Tsvetayeva's daughter, who in a letter from 1950 from exile in Turukhansk wrote to Pasternak: "Darkness and cold, here's Inferno, and the Orthodox are so stupid that they believe that sinners must necessarily roast, cook and lick something glowing...") also mentions Dante and his "sad hole" (tristo buco-Inferno XXXII, 2), which "is not a place of the
} 
these witnesses, Dante plays a double role: on the one hand, they "use quotations from The Divine Comedy to make a stand, argue or complain," ${ }^{, 4}$ and on the other hand, Dante remains the "noblest voice of humanity," 55 offering consolation even amidst unspeakable misery and hardship. Thus, Dante and Shemà, Christian culture and Jewish culture, prayer and poetry become one.

The Divine Comedy is finally like a form of "therapy," because "the modern man crushed by the machine of history has lost the status of a citizen," and when reading Dante "the regained sense of unity with the universe, finding himself in the cosmos and being rooted in transcendence will also restore the lost dignity of the human citizen." ${ }^{56}$ It is no coincidence that Dante will appear in various disguises (as an exile, pilgrim, politician, prophet or bard) in Poland of the $19^{\text {th }}$ century, especially in Poland of the "Great Emigration," and later in the $20^{\text {th }}$ century of the "Second Emigration" ${ }^{, 57} \ldots$.). He will also appear under different "pseudonyms", metonymies and antonomasias (Beatrice, Virgil, Ulysses, Ugolino, Francesca...), ${ }^{58}$ or directly under his own name or in his own work, as the central figure of literary reflection and self-reflection. Therefore, as critics used to speak about a "Dantean

flame but an annihilation of energy and light, absolute coldness, a frozen lake during the night, a hard-rock lake" (a quote from the Italian edition: Philippe JACCOTTET, La parola Russia, ed. Antonella Anedda (Roma: Donzelli, 2004), 53 and 55).

${ }^{54}$ Raniero SPEELMAN, "Ebrei italiani nel rifugio svizzero: asilo ameno o purgatorio?," in: Tra storia e immaginazione: gli scrittori ebrei di lingua italiana si racconatano, ed. Hanna Serkowska (Kraków: RABID, 2008), 48.

${ }^{55}$ Cesare Segre, "Se questo è un uomo di Primo Levi," in: Letteratura italiana, ed. Albero Asor Rosa, Le opere, v. IV. 2 (Torino: Einaudi, 1996), 506.

${ }^{56}$ Tadeusz SuCHARSKI, Polskie poszukiwania, 181, on Vincenz's essay Czym może być Dante.

${ }^{57}$ On the figure and function of a "bard," which in Polish imagination and poetic nomenclature links inseparably the names of Mickiewicz, Dante and "Vergil-prophet" from the Fourth Eclogue, see Stefania SKWARCZYŃSKA, “Aspekt wergiliański jednej z wypowiedzi Mickiewicza o Stefanie Garczyńskim i jego znaczenie dla wiedzy o wzajemnym stosunku obu poetów," in: EADEM, Pomiędzy historia a teoria literatury (Warszawa: PAX, 1975), 66. The attribution of prophetism to Dante, this time paired with Machiavelli, returns in Przemówienie do młodzieży florenckiej [Address to the Youth of Florence], delivered by Adam Mickiewicz on 21 April 1848. Calling for the unification and liberation of Italy from under the rule of all tormentors, the Polish bard observed: "The dream of Dante, Machiavelli, and your prophets, who called to you like the Jewish prophets: 'Woe! Woe!', and whom you did not understand, and murdered, tearing apart their heart and soul" (Adam Mickiewicz, Trybuna Ludów, in: Dzieła, v. XII (Warszawa: Czytelnik, 1955), 300).

${ }^{58}$ On the figures of The Divine Comedy and their various literary incarnations (and not only) in Polish literature of the 19th c. see the second part of Agnieszka Kuciak's book Dante romantyków, 73-135. 
code in Russian Symbolism,"59 one should all the more speak in reference to Polish literary culture, if not about a "system," then at least about a "paradigm of modern Dantism."

If we were to define the two major "motivation waves" of this paradigm and their immediate effects (first of all in the context of numerous translations ${ }^{60}$ ) in the $19^{\text {th }}$ and $20^{\text {th }}$ centuries, we might identify the principal, naturally interrelated, themes as follows:

A. Frequent comparisons between the visions of hell in The Divine Com$e d y$ and the modern hell of the living, which can be both the fiery hell of crematorium furnaces and the icy hell of Siberia and Gulag, or the hell of the "city of anguish"-Warsaw as the concrete allegory of the Last Judgment. This is a comparison which has a well-codified tradition in Polish literature dating back to the $19^{\text {th }}$ century: I am thinking here of a fragment of Lecture XXVIII from the second course of "Slavic Literature" (1842) at the Collège de France-the sacred text, the summa of all Romantic thought, in which Adam Mickiewicz proposed a distinction, henceforth canonical in the history of Polish literature, between "émigré literature" and "exile literature." With reference to the latter, which he called "Polish-Siberian literature," Mickiewicz observed:

That Siberia, which Russian writers rarely mention-although there are several odes extolling Russian victories in that country - that Siberia, so distant and so alien, now enters the realm of Polish poetry. Siberia is a political hell; it plays the same role as hell in the poetry of the Middle Ages, so well described by Dante. ${ }^{61}$

\footnotetext{
${ }^{59}$ See Lena SZILÀRD and Peter BARTA, "Dantov kod russkogo simvolizma," in: Parallelismi e rapporti tra il Trecento italiano nonchè la lingue e le culture romanze e slave. Materiali del Simposio internazionale, monograph issue Studia Slavica Academiae Scientiarium Hungaricae XXXV, No. 1-2, (1989): 61-95.

${ }^{60}$ Leaving aside the many partial translations (also of entire cantos; in 1781 the first Polish translation of Paradise I, 1-12 came out), we may list at least nine translations of the entire $D i$ vine Comedy over the last two centuries: 1860, translation by Julian Korsak; 1864-65, unpublished translation by Józef Ignacy Kraszewski (now published in part in A.F. De Carlo's doctoral dissertation, Dante nella Polonia del XIX secolo, 344-782); 1870, translation by Antoni Stanisławski; 1902 unpublished translation by Stefan Rawicz Dembiński (manuscript Ossolineum Library-Wrocław no. 4469 II); 1909, translation by Edward Porębowicz; 1932, translation by Jan Maria Michał Kowalski; 1947, translation by Alina Świderska; 2006, translation by Agnieszka Kuciak; 2012, translation by Jarosław Mikołajewski. The outcome is all the more surprising when compared with the number of translations in other cultures and languages close to Italian culture, for example Romanian culture, where we can identify "only" five translations of the entire poem.

${ }^{61}$ Adam MickiewICZ, Literatura stowiańska. Kurs drugi (lecture XXIII), transl. Leon Płoszewski, in: IDEM, Dzieła, v. X (Warszawa: Czytelnik, 1955), 285.
} 
In one of the last memoirs published by the Auschwitz-Birkenau State Museum, theatre director Józef Szajna, a camp survivor and author of a memorable performance Dante (1974), in reference to the relation of literary tradition to unspoken history ventured as far as to sarcastically cry out: "It is as if the tragedy of Aeschylus and Dante's Inferno called for concentration camps to be felt and accounted for" ${ }^{\prime \prime 2}$;

B. Therefore, generally speaking, the subject of polis and exile, but the perspective of Polish Dantism is obviously conditioned by the special relationship with history, which writers and intellectuals sustained in Poland after the collapse of the state as of the first half of the $19^{\text {th }} \mathrm{c.:}$ what is at stake here are the ideas of polis and exile, which assumed allegorical meaning and universal value. In Czym może być dziś dla nas Dante Stanisław Vincenz (who first wrote about "Dante and Mickiewicz" in 1940, shortly after his release from a NKVD prison in Stanisławowo) will equate epic, ethics and politics, since "ethics is founded on freedom," who, transcending the contemporary horizon, speaks in the name of "a community of the dead, living and future people." ${ }^{64}$ Similarly, in the chapter of his marvelous travel book Pamięć Włoch [The Memory of Italy], not incidentally titled Sztuka i polityka [Art and politics], another émigré essayist of the following generation, Wojciech Karpiński, stresses that the value of The Divine Comedy consists of the merger of "a cosmological and historiosophic vision [with] a political pamphlet, a personal settling of scores" of Dante with Florence, a place which for Karpiński, more than any other city, retains "the plain and visible - in buildings, paintings, political treatises and poems [...] - merger of individual aspirations with the aspiration of the group, fixed norms and values with transient forms of social life." ${ }^{, 65}$

C. This ethical concept of the polis directly linked with the religious, or rather philosophical and historiosophic motif of the spiritual growth of the individual and the possibility of his salvation, beyond the imaginary infernos and purgatories of life. It is possible to one's paradise lost (childhood, homeland, innocence, freedom) and the awareness that transcendence could be an antidote to history. It is connected with, as Vincenz says, "the feeling that

\footnotetext{
${ }^{62}$ A quote from the album Świat Józefa Szajny, ed. Krystyna Oleksy, Państwowe Muzeum Oświęcim-Brzezinka, 1995, p. 91. See also an article by Szajna "Dante żywy," in: Dante i slavenski svijet, v. II, 639-642.

${ }^{63}$ See Stanisław VinZEnZ, Dante i Mickiewicz, 64.

${ }^{64}$ IDEM, Czym może być, 215.

${ }^{65}$ Wojciech KARPIŃSKI, Pamięć Wtoch, (Warszawa: Fundacja Zeszytów Literackich, $2008^{3}$ ), 53.
} 
love is the core of the world." 66 Therefore, the ethical and epic subject of purification connected with Dante (and also, not surprisingly, with Cervantes) will return in Józef Szajna's manifesto of the "organic theatre", announced in 1977, i.e. three years after the first performance in Florence ${ }^{67}$ of his great play inspired by The Divine Comedy:

In my performances, Dante and Cervantes are pilgrims, as if missionaries wandering with their message across the world. That is why they are close to me. They set out a clear directive and proposal on how to develop oneself and one's environment and how to take on moral obligations for the benefit of the community. This proposal has for years corresponded to my audience, the vast majority of which are young people from different parts of the world. They treat coming to the theatre as purifying, as our kátharsis. ${ }^{68}$

Due to its central place in the history of Polish Dantism, and consequently also in the entire Polish modern and contemporary culture, ${ }^{69}$ it will be worthwhile to dwell longer, above all, on this third point, without forgetting, however, that the three basic themes mentioned above should be accompanied by a fourth one, which is strongly linked to all of them, especially the last one:

D. The theme of Beatrice and impossible love, which appears frequently in all Romanticisms, including the Polish ${ }^{70}$ (and which, as was mentioned in relation to Lechoń), we can also find in mature $20^{\text {th }}$-century poetry. It fills

${ }^{66}$ Stanisław VINCENZ, “Dantyzm w Polsce," in: IDEM, Eseje i szkice, 328.

${ }^{67}$ The world premiere at the Festival dei Popoli in Florence (1974); first performance - Warsaw, Teatr Studio, 20 April 1974. Dante by Szajna was staged several times during various international tours, including on one of the Croatian stages, and was subsequently shown in a completely new version under the title Dante 1992, premiere: Warsaw, Teatr Studio, 28 March 1992.

${ }^{68}$ Józef Szajna, "Teatr organiczny," in: Świadomość teatru. Polska myśl teatralna drugiej połowy XX wieku, (Warszawa: Wydawnictwo Naukowe PWN, 2007), 74-75.

${ }^{69}$ On "redemption" and its literary returns-interactions in the Polish "philosophy of action" and beyond, see Marina CiCCARINI, "Czyn i odkupienie: stała kulturowa między romantyzmem a XX wiekiem,” in: EADEM, Żart, inność, zbawienie. Studia z literatury i kultury polskiej (Warszawa: Neriton, 2008), 269-289.

${ }^{70}$ On the use and reminiscences of the figure of Beatrice in Polish Romanticism, apart from the chapter of Agnieszka Kuciak's book: Inkarnacje Beatrycze, czyli od Ewy ze snu do osoby patrzacej ku niebu, in: Dante romantyków, 91-111, see Krzysztof ŻABOKLICKI, Le Beatrici del romanticismo polacco, in: IDEM, Da Dante a Pirandello. Saggi sulle relazioni letterarie italo-polacche (Warszawa-Rzym: Accademia Polacca delle Scienze, Biblioteca e Centro di Studi a Roma, 1994), 5-14; on the gender interpretation of the relationship between the sexes in Nie-Boska Komedia by Krasiński see also Anton Sergl, "Mąż. Koncepcja płci w Nie-Boskiej Komedii Zygmunta Krasińskiego," in: Ciało-Pteć-Literatura. Prace ofiarowane profesorowi Germanowi Ritzowi, ed. Magdalena Hornung et al. (Warszawa: Wiedza Powszechna, 2001), 69-104. 
a serious gap, initially caused by the absence of Polish courtly lyric poetry, but not Petrarchism, which at that time was also at its peak, somehow merging with Dante in a new romantic concept, which supports all contemporary poetic images of the "greatest passion"-of course, also in its satirical, exposing and "avant-garde" versions, as in Konstanty Ildefons Gałczyński's Teatrzyk Zielona Gęś [Green Goose Theatre]:

The Green Goose Theatre is honored to perform:

Love

Personae: HE \& SHE

HE (poet): Mary, I love you. I love you as no one else before and after. As no one in the world. As no one in history. This is the love that neither Dante nor Don Juan had. Love. Do you understand what love is?

SHE (medic): I do. This is a mental hyper-metamorphosis resulting in hyper-kinesthesis, which leads to angiopathic neurasthenia.

HE: Thank you.

COURTAIN falls with an ominous swish. ${ }^{71}$

Similarly, in Stanisław Grochowiak's radio drama Virgil, whose plot interestingly connects our points A. and D.: the inferno it demonstrates includes the Auschwitz-Birkenau concentration camp where a Frenchwoman comes across a trace of her first husband murdered there. She is accompanied by another visitor, an American, and a local "Virgil," who cannot shake off the obsession with the past (in the movie made in 1976 based on this play, the role of the director of the Auschwitz Museum was played by the actor August Kowalczyk, who had survived two years in the actual camp as inmate number 6804):

American: Do you know The Divine Comedy? There was inferno and then Virgil led Dante to Beatrice, who led the poet to heaven. Down with Virgil! $!^{72}$

\footnotetext{
${ }^{71}$ Konstanty Ildefons GatCZYŃski, Miłość (1947), in: IDEM, Dzieła, v. III: Próby teatralne, ed. Kira Gałczyńska and Barbara Kowalska (Warszawa: Czytelnik, 1979), 470; we can also point to another 1947 micro-drama or "ballad" of Teatrzyk Zielona Gęś, spoken on the stage by Baritone Gżegżółka (to the tune of Żyli w pałacu hrabia z hrabina), titled Ballada podwórzowa o pewnym Dantem [Backyard ballad of a Dante], ibidem, 480-81. Similarly, the jocular name of Dante can be found after World War Two e.g. in Wielka liczba A Big Number] (1976), quasi-programmatical poetry by the Nobel laureate Wisława Szymborska, whose minimalist poetics owes much to Gałczyński's satirical tradition: "Cztery miliardy ludzi na tej ziemi,/ a moja wyobraźnia jest, jak była./ Źle sobie radzi z wielkimi liczbami./ Ciągle ją jeszcze wzrusza poszczególność. [...]/ Ale tego sam Dante nie zatrzymałby./ A cóż dopiero, kiedy nie jest się" [Four billion people on this earth,/ and my imagination is as it was./ It does not process big numbers that well./ It continues to be moved by singularity ... Yet Dante himself would not stop this./ Let alone when one is not], quoted after Wisława SzYMBorsKa, Poezje (Warszawa: Alfa, 1987³), 174.

${ }^{72}$ Stanisław Grochowiak, Dialogi (Warszawa: Państwowy Instytut Wydawniczy, 1975), 192.
} 
E. We should moreover reflect on what extent Dantism, also as the principal aspect of Polish "Italianism", is part and parcel of the canon of the European tradition of which Dante (along with other shamans) is a metonymic and even antonomastic sign. For Polish authors-something self-evident due to the tragic moments of history-Dante somehow impersonates all of our problems, complexes, Gombrowicz's "faces" and explosions of genius. One of the most magnificent tokens of this deep communion with Dante are the two stanzas of the poem Komedia boska [Divine comedy] by Julian Tuwim. Patterned on Eliot's fusion and confusion of historical and stellar time-space, "our stars" observed by a "foreign poet" who visits "bizarre Florence," are identical with Alighieri's stars. ${ }^{73}$ Furthermore, the reflection of, let us say the "sum total" of Eliot, Tuwim and the entire $20^{\text {th }}$ century, on the relationship between the individual genius and the relativity of the tradition of time-space, had its direct antecedents in Romanticism: its telltale traces can be discovered in the famous portrait of Eugene Delacroix, made probably immediately after Chopin's death, where the composer is depicted "like Dante" or, as the French would have it, "in Dante" (en Dante) (see Fig. on p. 66).

In this dual and uniform image of a raw profile of "dear Chopin" the French painter wished to stress, apart from the shared anguish of exile: Dante from his Florence, Chopin from his Warsaw, a complete incongruity and exchangeability of times and places, linguistic, painting and music signs, when we speak about such great geniuses of European art. ${ }^{74}$

\footnotetext{
${ }^{73}$ See Julian Tuwim, Komedia boska, in: IDEM, Rzecz czarnoleska (1929), Dzieła, ed. Juliusz Wiktor Gomulicki, Jarosław Iwaszkiewicz, Mieczysław Jastrun, Antoni Słonimski, v. II.2 (Warszawa: Wydawnictwo Jakuba Mortkowicza, 1955), 17 (it seems to be that the words bizarre in reference to Florence in Tuwin is a direct reference to Inferno VIII, 68: "e "1 Fiorentin spirito bizzarro" and is all the more significant than that in Porębowicz's "canonical" translations, where bizzarro is translated in "zawzięty"). Tuwim, like Gałczyński (see above, note 72), and then Wisława Szymborska (whose poetry seems to me to derive a lot from both these authors), proves his intimacy with Dante also through the jocular tone and satire, e.g. in the collection Cicer cum caule, czyli groch z kapusta. Panopticum i archiwum kultury (Warszawa: Czytelnik, 1958), where-among all kinds of strange texts, language games and caprices - there is (p. 104) a "Fantastyczny Katalog" [Fantastic catalogue], created by a "group of witty Krakow-based scholars, historians and bibliophiles", with a pamphlet (never published) by Karol Hubert Rostworowski $O$ ile ja i Dante stoimy wyżej od Żeromskiego? [By how much do I and Dante outshine Żeromski?], Kraków, ed. Gtos Narodu 8 (1925): 30; or a note (from the Silva Rerum magazine 1939, no. 3) about the translation of The Divine Comedy into the "Gypsy language" by the Romanian Roma Lazarescu (p. 302); or about "a German censor from Cologne" "who scrapped an ad in Rheinische Zeitung on the publication of Dante's Divine Comedy. The reason: one does not joke of divine matters" (p. 191).

${ }^{74} \mathrm{I}$ am indebted to Professor Jerzy Miziołek for drawing my attention to this famous drawing, preserved in the Louvre in Paris, most probably made by Delacroix in at least two versions, prior
} 
All that has been said so far leads to the conclusion that the primum mobile of modern Polish Dantism was primarily the link of poetry and history. In a fragment of one of his Harvard lectures on poetry, Czesław Miłosz, the Nobel Prize winner in 1980, spoke of "a special encounter between the individual and the historical, which means that events befalling the whole community are perceived by the poet as affecting him in the most personal way." And he added: "Poetry is no longer alienated then." find the key to fully understanding Dante's central role in modern Polish culture-as an "epic for the whole of humanity," capable of "capturing a community" which offers redemption and salvation. I want to stress that Dantism is in a sense deeply ingrained and in historiosophic reflection and in the postpartition poetic theodicy, the foundations stones of Polish "Romantic paradigm," in particular of Mickiewicz's Messianism. Using the stilted language typical of the symbolist-decadent stage (later ridiculed by the "heretics" of the following era, primarily, as usual, by Gombrowicz), the language he used to address his beloved Juliusz Słowacki, whose oeuvre teems with Dantean motifs and references, ${ }^{76}$ the spiritualist philosopher Wincenty Lutosławski observes: "This combination of poetry and metaphysics, of the ability of precise thinking and the gift of poetic diction, has not been known to humanity since Plato-perhaps with the exception of Dante."77 Are we not dealing here, however, leaving aside national pride and exaltation (invariably irritating, but pardonable and "defensible" in those whose national state is in jeopardy or no longer exists due to others' aggression ${ }^{78}$ ), in fact with the very

to and immediately after Chopin's death; the illustration can be found online at: http://www.google.com/imgres?q=Chopin+en+Dante.

${ }^{75}$ Czesław Mıosz, Świadectwo poezji. Sześć wykładów o dotkliwościach naszego wieku (Paryż: Instytut Literacki, 1983), 76 (lecture V: Ruiny i poezja [Ruins and Poetry]).

${ }^{76}$ Apart from the aforementioned article by Bruno Meriggi (see note 6 above), see Stanisław Windakiewicz, Badania źródtowe nad twórczościa Stowackiego (Kraków: [s.1.], 1910); Stanisław Stroński, "Wpływ Dantego w 'Grobie Agamemnona'," Pamiętnik Literacki (1909): 152157; Stanisław ŁEMPICKI, "Miłość dantejska w poemacie 'W Szwajcarii'," Pamiętnik Literacki No. 1 (1924/25): 155-182; Nelly Cimino, "L'influenza di Dante nell'Anhelli," Rivista di cultura No. 3 (1926): 66-70; Wanda De Andreis WyноwskA, “Dante nell'opera di Giulio Słowacki,” Rivista di Letterature Slave No. 5 (1932): 342-374; Jarosław MACIEJEWSKI, Florenckie poematy Stowackiego (Wrocław: Zakład Narodowy im. Ossolińskich, 1974).

${ }^{77}$ Wincenty LuTOSŁAWSKI, "Metafizyka w poezji Słowackiego," Biblioteka Warszawska (January 1909): 31, quoted after: Halina FLORYŃSKA, Wincenty Lutosławski-metafizyka jaźni i narodu, in: Polska myśl filozoficzna i społeczna, v. III, ed. Barbara Skarga (Warszawa: Książka i Wiedza, 1977), 183.

${ }^{78}$ I refer here to the differentiation of the categories of "defensive nationalism" and "aggressive nationalism" as put forth by Ewa Thompson in her Trubadurzy Imperium. Literatura rosyjska i kolonializm (Kraków: Universitas, 2000). 
"perfect overlap of Dante's personality with the cosmic external and the mutual interpretation of both, the harmony of soul and the world," sustained by the "firm discipline" of terza rima, addressed by Ernst Robert Curtius a few decades later ${ }^{79}$ ? Thus the $20^{\text {th }}$ century will inherit as well as rejuvenate a tradition (truly in Eliot's sense ${ }^{80}$ ), which from Miłosz, Vincenz, Szajna and others harks back directly to Wyspiański, Mickiewicz, Słowacki, and in reality to Dante himself and further still ... In this sense Gombrowicz's book $O$ Dantem of 1968 is truly, as Zdzisław Łapiński observed, a "dialogue of the dead"81 and is only a link in the chain. While the link is antiphrastic and provocative, it is in full harmony with the "soteriological" and "historiosophic" line of Dantism (not only the Polish one), totally disgusted by the particularist and nationalist overuse of "great individuals" of the past and their transformation into "form" (hence, precisely, the seeming "Dantophobia" of Gombrowicz):

Contact with the past is, then, an incessant development of it, bringing it to life ... [...] This book, The Divine Comedy—still before me on the table-is six hundred years away. What should the past of the human race be for me? I am resting on a huge mountain of corpses - those who have already passed away. What am I resting on then? [....] Should I explore the past looking for people in it, or should I just look for a certain detached dialectics of development $?^{82}$

We will neither be surprised by the words of the author of Ferdydurke nor be offended by them (like Ungaretti), if we read them in the context of a statement by Stanisław Brzozowski, the great expert on Italian culture, who died at the age of thirty in Florence a century ago and who-over six decade before Gombrowicz, surprisingly preceding all existential hermeneutics—cried out:

If such contemporary criticism wanted and could re-live such phenomena as Rabelais, Dante, Shakespeare, Goethe, if, shaking off the dust of erudition from them, it allowed its soul to enter into direct and live contact with them! If these names were to become a psychological temptation, instead of being topics for scholars and so few informative treatises ... How important such critical resurrection would be! $!^{83}$

\footnotetext{
${ }^{79}$ Ernst Robert CurTius, Literatura europejska i tacińskie średniowiecze, ed. Andrzej Borowski (Kraków: Universitas, 1997), 388.

${ }^{80}$ On this topic see e.g. the most recent collection of criticism ed. Giovanni Cianci and Jason Harding T. S. Eliot and the Concept of Tradition (Cambridge: Cambridge University Press, 2001).

${ }^{81}$ Zdzisław ŁAPIŃsKI, Ja, Ferdydurke. Gombrowicza świat interakcji (Lublin: Redakcja Wydawnictw KUL, 1985), 89.

${ }^{82}$ Witold Gombrowicz, $O$ Dantem, p. 24 and p. 40 and 42.

${ }^{83}$ Stanisław BRzozowski, "Sztuka i społeczeństwo (1903)", in: IDEM, Eseje i studia o literaturze, ed. Henryk Markiewicz, B.N. series I no. 258, v. I (Wrocław: Zakład Narodowy im. Ossolińskich, 1990), 109.
} 
Like Gombrowicz, who in 1953 began his Diary with the name of Dante, he will conclude it referring to the greatest of poets-worshipping not so much his name but "genuine humanity":

The Divine Comedy is not enough for me. I seek Dante in it by but fail to find him, since the Dante history transmitted to me is precisely the author of The Divine Comedy. All the great people are no longer people but accomplishments only... Explain, pilgrim, how to get down to you $?^{84}$

For Gombrowicz, what really offers sense and reality to things among among great and small "people" and their "accomplishments," the "disconnected dialectic of development," is pain:

Yes, Pain makes it real. Only pain is capable of combining, through time and space, this pain brings generations to a common denominator. It [hell] exists, it exists, it does $!^{85}$

In a scintillating critical text about Gombrowicz, Czesław Miłosz wrote:

There is nothing more depressing than to see people who themselves seem to follow the collective manias, haunted by their own, brightest revelation, while their complete, ape-like, dependence on propaganda and advertising could be calculated with the help of perfected computers. A concentration camp that thickens humanity is the model and test of our beautiful age. There also takes place in the ultimate and extreme form the game of mutual dependence between master and servant, which is constantly repeated in Gombrowicz's work. ${ }^{86}$

The interplay of power and the annihilation of the individual inevitably result in a less benevolent state (il peggio, Paradise VIII, 115), i.e. to the enslavement of people and concentration camps. This is a contemporary hell. And it is precisely in answering them that Dante and his journey can still be helpful today. The core of the problem is the ethical principle of great poetry, always fundamentally understood as an epic, a historical-political story about

\footnotetext{
${ }^{84}$ Witold Gombrowicz, $O$ Dantem, p. 46 and p. 72.

${ }^{85}$ Ibidem, p. 60 and p. 66. In fact, Stanisław Brzozowski in his 1903 essay Sztuka i spoteczeństwo wrote: "There are two literatures: the literature of the afflicted and suffering, those who seek and those who protest warriors and victors, those those who bleed and whose moans are a mockery the literature of Job, Jeremiah, Ezekhiel, Dante, Cervantes, Calderon, Lope de Vega, Byron, Dickens and Thackeray, Carlyle and Ruskin, Mickiewicz, Słowacki and Krasiński, Gogol and Dostoievsky, Turgenev and Tolstoy. And there is another literature of beautiful form, flatterers, courtiers and spendthrifts, servile and self-loving minds" (op. cit., p. 104).

${ }^{86}$ Czesław MiŁosz, Kim jest Gombrowicz?, in: IDEM, Prywatne obowiązi (Paryż: Instytut Literacki, $\left.1980^{2}\right), 144$.
} 
contemporary times. That is why, while writing about such a masterpiece of theatre at the beginning of the $20^{\text {th }}$ century as Stanisław Wyspiański's Wedding, Stefania Skwarczyńska emphasized the "apparent paradox" consisting of the fact that "the more an artistic creation comes close to a global status, the more it expresses universal and timeless values, the more it is imbuedlike Dante's The Divine Comedy — with its contemporary history." 87 This is not a question of the updating of works and people from the past, but rather their coexistence in tradition (Eliot), which the theatrical genius of Wyspiański felt perfectly well, transforming or rather disguising Krakow castle on Wawel Hill as the Acropolis of ancient Greece; and then the genius of Jerzy Grotowski, who, when performing Acropolis by Wyspiański, moved Wawel, the sacred place of Polish authority, and enclosed it in the death camp in Auschwitz. ${ }^{88}$

Especially instructive in this context and virtually exemplary for a large part of the history of Polish Dantism is the position of the writer and exile Czesław Miłosz-a crossover of tradition and innovation and a successful synthesis of artistic commitment and reflection on human history and individuality. While in Miłosz's oeuvre there are no texts dedicated entirely to The Divine Comedy and Dante, in his poetic oeuvre and essays we can find scattered nearly all aspects of "poetic Dantology" of the $19^{\text {th }}$ and $20^{\text {th }}$ centuries, not only the Polish. ${ }^{89}$ Furthermore, it is in him, a long-time professor of Slavic and comparative literatures at Berkeley University, that there coexist and nearly merge the "Polish" (Mickiewicz-Brzozowski-GombrowiczVincenz), "Russian" (Pushkin—Dostoevsky-Mandelstam—Brodsky), "Anglo-American" (Blake-Eliot-Pound-Auden-Frost-Pinsky) and "Anglo-Irish” (Yeats-Joyce-Beckett- Heaney) lineages. Miłosz combines all of them via the gnostic and Manichean poetics of his beloved Swedenborg and the Franco-Lithuanian poet, Oskar Miłosz de Lubicz, Czesław's relative to

\footnotetext{
${ }^{87}$ S. SKWARCZYŃSKA, "O randze artystycznej Wesela Wyspiańskiego (U progu filmowej wersji Andrzeja Wajdy)," in: EADEM, Pomiędzy historia a teoria literatury, 87. In order to explain why undoubtedly works of universal art can be unknown to the majority, he adds: "But in order for its greatness to be universally recognised, it is necessary to know the national origin of the masterpiece, its provenance."

${ }^{88}$ In the reviews of Grotowski's Akropolis from the mid-1960s "critics compared it to the visions by Dante and Hieronimus Bosch" (Zbigniew OsIŃSKI, Grotowski i jego Laboratorium, (Warszawa: Państwowy Instytut Wydawniczy, 1980), 156).

${ }^{89}$ I deal with Miłosz's Dantism and his complex intertextual lines in: Luigi MARINELLI, “"Tam jest mój dom.' Wokół dantyzmu Miłosza," an unpublished paper delivered at the international conference Miłosz i Miłosz (Kraków: Wydawnictwo UJ, May 2011).
} 
whom he attributes his own genuine poetic initiation. ${ }^{90}$ In this perspective, of special importance is the vision of poetry and tradition expressed in the book given Blake's title The Land of Ulro. It seems that the essence of the Miłosz/ Dante question ${ }^{91}$ is the celebration of the freedom of human imagination (and art) above all possible limitations on the part of society and even Nature. Eternal 'imaginary' life — as he calls it—is shared by great 'visionaries' such as Dante, Swedenborg, Blake, Mickiewicz, and Oskar Miłosz:

What does Blake's faith in eternal "imaginative" life mean? It is precisely thisthat the activity of imagination (i.e. the inspirations of the Holy Spirit) foreshadows a liberated imagination, beyond the physical body and beyond nature, by analogy with the creative act, which is, to a large extent, a "way out of the body." Blake's Heavens and Swedenborg's Inferno treated exactly the same way as Dante's Heaven and Hell, i.e. as real b e c a u s e imagined. ${ }^{92}$

He will say on another occasion as follows: "Eliot's work tries to prove that imagination, and thus religious poetry, may regain its previous privileges." 93

Blake's "leaving the body" is, in Miłosz's poetry, a clear reminiscence of Dante's trasumanar (in Porębowicz's translation: przecztowieczenie or trans-humanization; Paradise I 70). It is here, it seems, in the announcement of the regaining of Paradise (an inner one, "real only because it is imaginary") that - despite Inferno and (earthly) Purgatory-one can find the essence of Dante's ethical interpretation by Poles (and not only):

Swedenborg's space is an inner one [...] Human inner states dependent on the orientation of human will (love) assume the shape derived from sensual sensations on our earth, but there is no "objective" netherworld, i.e. only someone's good and evil are "objective". "What you are is how you see": since all nature is composed of signs, now the signs become somewhat autonomous and make up the alphabet of joy or torment. [...] Inner spaces are, then, subjective creatures, different in different people, and that is why there is a plethora of heavens and hells. ${ }^{94}$

\footnotetext{
${ }^{90}$ The subject of Dante's presence in Oskar Miłosz's poetry was addressed by J. BellarminNoël, Miłosz et Dante: “'La Divina Commedia' et les noms des personnages de 'L'Amoureuse Initiation'," in: Dantismo Russo e cornice europea, v. II, 127-135.

${ }^{91}$ Apart from Piotr Salwa, on this subject see also: Andrea CecChERElli, "Miłosz e Dante," in: Italia Polonia Europa. Scritti in memoria di Andrzej Litwornia, ed. Andrea Ceccherelli et al. (Roma: Accademia Polacca delle Scienze, 2007), 98-113.

${ }^{92}$ Czesław MıŁosz, Ziemia Ulro (Kraków: Znak, 2000), 167.

${ }^{93}$ IDEM, "Myśli o Eliocie," in: IDEM, Prywatne obowiazki, 160.

${ }^{94}$ Ibidem, 167-168.
} 
In order to comprehend how indefatigably Miłosz sticks to what could be called the "poetics of trans-humanization", one must link the aforementioned excerpt from The Land of Ulro with Heaven, one of the most magnificent poems from the posthumous poetry volume Wiersze ostatnie [Last Poems] (2006) - the motto referring to the metaphoric interpretation of the words "Who art in heaven" from the Lord's Prayer, the poem begins as follows: "Jak daleko sięgam pamięcią, zawsze chciałem być w niebie" [As far as I can remember, I have always wanted to be in heaven]. In a self-commentary immediately following the poem, he adds: "The author of this poem seems to notice that faith in God is founded on contacts with people and on what we call human civilization. According to the Bible, God created man in his image and likeness, and is not human creative ability a most divine feature?" 95 It was this divine "image and likeness" of man which the old poet seems to profoundly believe in and which made him reject in a 1970s essay-following Gombrowicz but in a totally different mannerDante's Inferno, which he called "the least persuasive of the three parts of The Divine Comedy for the contemporary reader.",96

In addition to the fundamental problem of the need for a metaphysical reading of the world and the possible compatibility between poetry, religion and science-increasingly difficult and seemingly impossible, yet redemptive for modern humankind - during the seventy years of Czesław Miłosz activity as a poet ${ }^{97}$ there appear numerous other Dantesque subjects and motifs. A poetic and autobiographical motif of memory and exile, of course, occupies a prominent place. Miłosz will say in his Nobel address: "Dante is a patron saint of all poets in exile, who visit their towns and provinces only in remembrance, is always Dante. But how has the number of Florences increased!"98 It is therefore in order to return to that Polish-Russian parallelism (mentioned earlier in connection with Mandelstam's Dantism) through the pairing of Miłosz and Brodsky, two great Slavic poets, friends and Nobel Prize laureates for literature (1980 and 1987, respectively),

\footnotetext{
${ }^{95}$ See Czesław MiŁosz, Wiersze ostatnie (Kraków: Znak, 2006), p. 68 and p. 70.

${ }^{96}$ O piekle, in: IDEM, Ogród nauk (Paryż: Instytut Literacki, 1981), 84; it should be noted that Miłosz does not seek to provoke à la Gombrowicz, but tries to explain "in positive terms" his inhibitions towards this canto, the cause of which lies in the expressive power of a poem which we can no longer comprehend; nor can we comprehend the fantastic topography, the historical, allegorical and political senses and, in particular, the concept of evil.

${ }^{97}$ Since his youthful polemics with the avant-garde, he did not hesitate to declare that an intellectual writer, even a progressive and socially engaged one, can only be a writer "with Mickiewicz and Dante at hand" (Czesław MıŁosz, List do obrońców kultury (1936), in: IDEM, Przygody młodego umystu (Kraków: Znak, 2003), 151).

${ }^{98}$ Czesław MıŁOsZ, Nobel Lecture, bilingual edition (New York: Farrar Straus Giroux, 1980), 45.
} 
both emigrants in the US, "a land of great solitude" purgatory" for Brodsky (compared to Venice, where he was buried and which he considered to be his own "personal vision of Paradise"). ${ }^{100}$

It is on the one hand true what Irena Grudzińska-Gross, a Polish-American scholar, wrote in her fundamental book, namely that even in their different concepts of expulsion and of the language of its description, which she calls "Ovidian" and "Dantean," the "magnetic field" between Miłosz and Brodsky is expressed:

Legend has it that in his exile, Ovid was penning poems in the vernacular languageBrodsky would be a continuator of this tradition, even if his exile was nowhere near as dramatic as that of the Roman poet. We can say about Miłosz, in turn, that he continued the tradition of Dante, who until the end of his days wrote in his own "dialect." Miłosz had a completely different approach to language than Brodsky. ${ }^{101}$

One is made aware of the understandable correspondence of the subject of death and language in Brodsky (addressed by M. Lotman ${ }^{102}$ ) and Miłosz's "faithful mother tongue" as an anchor of salvation and ultimate source of one's individuality: "But without you, who am I"? ${ }^{103}$

On the other hand, in the microcosm of these writers we also encounter what we have already said about the relationship of Mandelstam and Dante. Brodsky, who admired Polish poetry, ${ }^{104}$ especially Miłosz, whom he considered

${ }^{99}$ Czesława Miłosza autoportret przekorny. Rozmowy przeprowadzit Aleksander Fiut (Kraków: Wydawnictwo Literackie, 1994), 123-125.

${ }^{100}$ Quoted from the Italian edition: Iosif BRoDSKIJ, Fondamenta degli incurabili (Milano: Adelphi, 2004), 21.

${ }^{101}$ Irena GrUDZIŃSKA-Gross, Miłosz i Brodski-pole magnetyczne, introduction Tomas Venclova (Kraków: Znak, 2007), 234. For Brodsky's recreation of the myth of poetic exile, with with a unique triple relationship- Dante, Mandelstam and himself-with the city of Florence in the background, see David M. BETHEA, Joseph Brodsky and the Creation of Exile (N.J.: Princeton University Press, 1994).

102 Mikhail ŁotMAn, "Poet i smert' (iz zametok o poetike Brodskogo)," in: Blokovskij sbornik XIV, ed. L. Pild and G. Ponomareva (Tartu: Tartu Ülikooli Kirjastus, 1998), 188.

${ }^{103}$ For a succinct analysis of a famous poem Moja wierna mowo [My faithful language], in: Luigi MARINELLI, "Le témoignage et la compassion: les attitude du sujet lyrique dans l'oeuvre de Czesław Miłosz, Zbigniew Herbert et Wisława Szymborska," in: Le témoignage dans la littérature polonaise $d u X X^{e}$ siècle, ed. Hanna Konicka et Charles Zaremba (Paris: Institut d'études slaves, 2008), 193-195.

${ }^{104}$ See e.g. Iosif BrodskiJ, "Lettera al lettore italiano," transl. G. Forti, in: Z. Herbert, Rapporto dalla città assediata, ed. Pietro Marchesani (Milano: Adelphi, 1993), 11-21. On Brodsky's "Polonism"/"Polishness" see also: J. ŚLASKI, "Iosif Brodskij e la sua finestra polacca sul mondo," in: Nei territori della slavistica. Percorsi e intersezioni. Scritti per Danilo Cavaion, ed. Cinzia De Lotto and Adalgisa Mingati (Padova: Unipress [2006]), 376-386. 
"one of the most eminent poets of our time, if not the most eminent," 105 comes closer to Dante not only thanks to the "canonical" Russian translation by Lozinsky and the Dantism of his "national" poetry (first and foremost Pushkin, Blok, Ivanov—and more generally the Symbolists—naturally Mandelstam, Akhmatova, Tsvetayeva...), but also thanks to Polish poetry, starting with Mickiewicz. It is indisputable that from both the intertextual perspective and the general "poetic aura," and even from a biographic perspective, the Brodsky-Mandelstam-Pushkin-Dante lineage is compared to the Miłosz-Gombrowicz-Mickiewicz-Dante line. Besides, in the case of both Miłosz and Brodsky, their relationship to The Divine Comedy is naturally enhanced by the lectura Dantis of other writers of English or US extraction, starting with Blake (with the special case of Brodsky, as well as favourite Polish poets, especially Miłosz ${ }^{106}$ ). In the latter's case we must not neglect that fact that the first American authors of an anthology of Miłosz's poetry included poet and critic Robert Pinsky, the renowned author of a poetic translation of Inferno. ${ }^{107}$ It is also telling that as a writer, Pinsky indicated as his principal predecessors the most "Dantesque" names in the entire history of English literature, such as Coleridge, Arnold, Eliot, and Auden. To my mind, what Valentina Poluchina wrote about Brodsky can be referred to Miłosz, toonamely that Dante provided him with all the fundamental philosophical categories for "universe: man - time, faith - love, creativity (art, poetry) language" ${ }^{\prime 108}$. On the other hand, one must notice that the Dantism of both the

${ }^{105}$ A text written by Brodsky in connection with Miłosz's nomination to the 1978 Neustadt Prize for Literature, initially published in World Literature Today 1978, no. 3.

${ }^{106}$ In this context, it is interesting to read the analysis of Zofia (the Polish version of the name "Sophia," which etymologically means: "knowledge," "wisdom - the soul of the world"), a programmatic poem Brodsky wrote in 1962, the year he first read Dante. In it, he restored to Russian poetry the unused word "soul" (duša). Jadwiga Szymak-Reiferova observed that he did it via significant, graphic rhymes (AD/klAD/chlAD, or: "Inferno/ Treasure/ Coldness"), stressing the opposition between shadow and light, body and the mystical soul of the world (See Jadwiga SZYMAK-REIFEROVA, “Zof'ia,” in: Kak rabotaet stichotvorenie Brodskogo, edited collection, ed. Lev Losev and Valentina Poluchina (Moskva: Novoe Literaturnoe Obozrenie, 2002), 10-32).

${ }^{107}$ See Czesław MıŁosz, The Separate Notebooks: Poems, ed. by Robert Pinsky, with Renata Gorczynski and Robert Hass (New York: , 1984); R. PINSKY, The Inferno of Dante: A New Verse Translation, with notes by Nicole Pinsky and foreword by John Freccero (New York: Ecco, 1996). On Pinsky, Dante's translator, see the pages dedicated to him in Chapter 6: "Il Poeta tradotto da poeti americani. Alla ricerca della perfetta 'transmutazione musaica", in: Ronald DE Rooy, "Il poeta che parla ai poeti". Elementi danteschi nella poesia italiana ed anglosassone del secondo Novecento (Firenze: Cesati, 2003), 231-254.

${ }^{108}$ Valentina PoluchinA, "Pleasing the Shadows. Brodsky's Debt to Puškin and Dante", in: Firenze e San Pietroburgo. Due culture si confrontano e dialogano tra loro, collected edition ed. A. Alberti and S. Pavan (Firenze: Università degli studi di Firenze, 2003), p. 155 and p. 154. 
famous Slav poets of the second half of the $20^{\text {th }}$ century originated and developed in a true intertextual vortex, which has not been examined in depth to date. ${ }^{109}$ Moreover, because of the "total," that is, the deliberately multicultural and multilingual nature of their reflection on tradition, Miłosz and Brodsky conclude in their literatures the stage of modernity and open up a new stage of Dantism. At the root of the classicism and shared worship of the dead is the poets' faith, the "call of transcendence inscribed into the very nature of being human." 110 Miłosz invokes it (in Italian!) in his wonderful 1990 poem titled Dante 111 : "Wrodzona człeku, bogokształtnej sfery/ Oskoma wieczna / La concreata e perpetua sete, The inborn and the perpetual desire / Del deiformo regno-for a God-like domain" (Paradise, II, 19-20, transl. E. Porębowicz). Poetry "transcends doctrinal philosophy, which cannot renounce or transcend the mind; it reaches to the heights of revelation and can express it; it does transcend beautiful appearance; [...] the revealed truth and its poetic form are one and the same thing.," In turn, in his essay "In the Shadow of Dante" Brodsky wrote: "poetry expresses in the most faithful form the collaboration of ethics and aesthetics." 113

Limiting oneself to but one language or "national" context is impossible and virtually absurd, especially when one talks about such giants. It is interesting, however, to return to the uniquely Polish context and to suggest a few tentative conclusions. First of all, we should ask about the contemporary legacy of the motifs and traditions of modern Polish Dantism, whose main

\footnotetext{
${ }^{109}$ One could develop this inherently comparatist topic by taking as the starting point "PolishIrish-American" Dantism, which links two translator-poets, i.e. Stanisław Barańczak and the Nobel Prize winner Seamus Heaney. However, this topic is also very broad and virtually ignored by critics. I can only signal it here, leaving its more adequate discussion for another occasion. On the Dantism of Seamus Heaney, who himself points to its direct relation with the Dantism of Osip Mandelstam, I will limit myself to referring the reader to the paragraph of Il Dante versatile di Seamus Heaney and to the chapter "Viaggio dantesco in Irlanda. Dante e la Divina Commedia nell'opera poetica di Seamus Heaney" of the aforementioned text by Ronald De Rooy, "Il poeta che parla ai poeti”..., respectively p. 60-63 and 159-193.

${ }^{110}$ Czesław MıŁosz, Rok myśliwego (Paryż: Instytut Literacki, 1990), 27. The term "call” used by Miłosz means an "appeal" and refers to St. Paul's "vocation". Rm 8:30 reads as follows: "Quos autem praedestinavit, hos et vocavit: et quos vocavit, hos et justificavit: quos autem justificavit, illos et glorificavit." The notion was adopted and commented extensively by St. Augustin, St. Thomas Aquinas and Dante himself (see Lisa CATTANEO, Dante tra Paolo e Isaia, esp. chapter 2: La "vocatio" in Paolo e Dante, available online at: http://www.bicudi.net/percorsi/dante/03vocatio.htm).

${ }^{111}$ Czesław MiŁosz, Dante (in the series Dalsze Okolice, 1991), reprint in: IDEM, Wiersze, v. 4 , (Kraków: Znak, 2004), 284.

${ }_{112}$ Erich Auerbach, Studi su Dante [Studies on Dante] (Milano: Feltrinelli, 1983), 90-91.

113 Josif BrodskiJ, W cieniu Dantego, Italian version: All'ombra di Dante, 45.
} 
tendencies I have tried to highlight in this article, perhaps too succinctly. What is it that we have accepted (or rejected) of it? Is Dante a "live presence" or only a "cumbersome presence," as the titles of the two most recent essays by the Italian Studies scholar Piotr Salwa imply? The most appropriate and impartial answer to such a question could be as follows: great artists by their very nature are always "alive" and at the same time "cumbersome." All signs of this duality can also be found in today's Poland. And that is why, although it may be too early to talk about the Dantism of writers (it is a fact that Przemysław Czapliński's most recent book dedicated to the "grand narratives" of Polish "later modernity" does not reference Dante at all), ${ }^{114}$ at least from the perspective of Dante Studies one must observe that 1989 is the date of a clear separation with the past. The exhaustion of the cultural and poetic potency of the "Romantic paradigm," which was authoritatively pronounced by Maria Janion in her famous essay from the years 1990-92, ${ }^{115}$ inevitably also concerned the vision and reception of The Divine Comedy created within this paradigm and cultivated there for a long time. One could even risk the hypothesis that apart from the "ethics" of Dante of Polish Modernism, there is nowadays a reception that is primarily "aesthetic," which is evidenced by, among other things, the proliferation of translations, for the first time also translations of Latin texts and other works that have remained outside the Polish canon of Dante, traditionally limited to Poema Sacro and Vita Nova, ${ }^{116}$ as well as the fact that the new translators, individually and collectively,

\footnotetext{
${ }^{114}$ See Przemysław Czapliński, Polska do wymiany. Późna nowoczesność i nasze wielkie narracje (Warszawa: Wydawnictwo W.A.B, 2009). We should note moreover that Dante's name does not appear in any questionnaires or votes of the 1990s dedicated to the reading canon, published in specialist periodicals and accounted for in Czapliński's book in the notes to the chapter titled Kanon, 227-276.

${ }^{115}$ See Maria JANion, "Zmierzch paradygmatu” [The Decline of the Paradigm], in: EADEM, Do Europy tak, ale razem z naszymi umartymi (Warszawa: Sic!, 2000), 19-34.

${ }^{116}$ See Dante AlighiERI, O języku pospolitym (De vulgari eloquentia), ed. Włodzimierz Olszaniec (Kęty: Antyk, 2002); IDEM, Monarchia, ed. Władysław Seńko (Kęty: Antyk, 2002); IDEM, Biesiada (Convivio), ed. Magdalena Bartkowiak-Lerch (Kęty: Antyk, 2004). In this respect the unique Polish situation does not differ that much from the situation in other countries. In reference to Russia, too, Michele Colucci observed that some fifteen years ago it was characteristic that "far less attention was dedicated to Dante's The Banquet, Monarchy and On Eloquence in the Vernacular, and his poems than to Vita nova and, naturally, the Comedy (Michele ColucCI, "Dante in Russia e nella russistica occidentale negli ultimi venticinque anni" (1995), in IDEM, Tra Dante e Majakovskij, 195). Incidentally, in Poland Vita nova had a variety of translations: Gustaw Ehrenberg (1880), Artur Górski (1915), Teofil Husarski (1921), Edward Porębowicz (1934 and many other editions), while in the case of Poems, Le Rime, we musts note one
} 
seriously and profoundly, addressed the question of Dante's translatability and reception within their own culture, ${ }^{117}$ for the first time not oblivious to its "minority" position in the European ecumene.

In a bilingual pamphlet published a few years ago, Jarosław Mikołajewski, a middle-aged poet and critic, a major translator of Italian literature, posed two fundamental questions: "Why?" and "How?" to translate Dante into Polish today? His replies were linked to and focused on the aesthetic: to translate Dante means to offer to those who cannot read him in the original the chance to create and receive new works of art, e.g. music, "which transforms dumbstruck people." 118 Translation as "organization" (organizzar, which reverses the order of the title of a volume of Pasolini's poetry ${ }^{119}$ and which, at least in this context, seems incongruous to Mikołajewski) precedes and supports someone's "transcending the boundaries of the human" (trasumanar). Another sign of Dante being permanently "alive" and "cumbersome" is the fact that within a few years Mikołajewski, denying his earlier ostensible principles and methods, changed his mind a few times as to "how" to best translate Dante for the contemporary Polish reader. At the end of the day, he focused on a new complete version of the Comedy... in prose (getting rid even of free verse and any metric or rhythmic organization, save the division of the text into pseudo-verses and pseudo-terza rima, which incessantly "remind" one of the poetic nature of the original text).

interesting edition, a unique luxury Italian and Polish publication: Dante ALIGHIERI, Pieśniarz, ed. Juliusz Feldhorn (Kraków-Roma: Sztuka-Książka-Wydawnictwo, 1926).

${ }^{117}$ See the debate between many different contemporary translators of Dante's oeuvre, whose transcript titled Boski Dante was published by Literatura na Świecie no. 4 (1995): 2-44.

118 Jarosław MikoŁAJEwski, Tradurre Dante in polacco (Udine: Forum, 2004), 11. A specific example referred to by Mikołajewski is the oratorio The Gardens of Josaphat (premiere, April 2002) by Jan Kanty Pawluśkiewicz, a contemporary composer and painter (b. in Tarnów in 1942), whose libretto is based on The Divine Comedy, inspired especially by Canto III of Inferno (the poem that has arguably made an indelible imprint on the Polish imagination), p. 25-27; translated by Edward Porębowicz: "Okropne gwary, przeliczne języki, / Jęk bólu, wycia, to ostre, to bledsze, / I rąk klaskania, i gniewu okrzyki... / horrible dialects, / Accents of anger, words of agony, / And voices high and hoarse, with sound of hands." Interestingly, during the celebrations of the $70^{\text {th }}$ anniversary of the Carpathian town of Stalowa Wola, on 11 November 2008, Pawluśkiewicz presented a cantata inspired by The Divine Comedy, titled Venetian Tales of Hell and Paradise, unceremoniously merging Dante's texts with those by the Krakow poet Leszek Aleksander Moczulski.

${ }^{119}$ A reference to the volume of poetry Trasumanar e organizzar (1971) by Pier Paolo Pasolini, translated in part into Polish by Mikołajewski himself as Przekraczać granice człowieka i organizować [To transcend the limits of the human and to organize] in the collection: Pier P. PASOLINI, Bluźnierstwo. Wybór poezji, ed. Jarosław Mikołajewski (Warszawa: Wydawnictwo Teta Veleta, 1999), 103-131. 
In conclusion, let us say that if in the present situation the coexistence of the "old" with the "new" is particularly visible, one can expect that such a relationship will prove fruitful for the development of the new Polish Dantism. The legacy of the $19^{\text {th }}$ century (the "Great Emigration," later transformed in the $20^{\text {th }}$ century into the "Second Emigration") has been critically analyzed in Agnieszka Kuciak's most recent study on Dante polskich romantyków [Dante of Polish Romantics], while Andrzej Litwornia's book on Dante's reception in Polish pre-Romantic culture and innumerable $19^{\text {th }}$-century translations of a few fragments, in particular Inferno (including Canto III) and various critical texts, due to their fragmentariness, erudition and focus on anecdote (characteristic of the work of the prematurely deceased scholar) seems a proposal for a comprehensive, postmodernist compendium (encyclopedia?) about Dante and Dantism in Poland.

Such a compendium might include, for the time being in a haphazard fashion, new translations, in terza rima or prose (which is harder?), and even translations from languages other than Italian ${ }^{120} \ldots$ It would also include the most recent accomplishments of Polish and foreign (translated) Dantology, ${ }^{121}$ and naturally Lectura Dantis, which opened the Verba Sacra Festival of Catholic Culture in Poznań in 2002. Further on we can list the woodcuts by Jerzy Panek, the paintings by Grzegorz Bednarski and the Dantesque sculptures by other contemporary Polish artists, ${ }^{122}$ and finally Zbigniew Preisner's music homage to Dante in Krzysztof Kieślowski's film La double vie de Veronique, where the singer in the heart-rending concert scene sings a text

\footnotetext{
${ }^{120} \mathrm{I}$ am referring in particular to an interesting, from the poetic point of view, edition of Inferno, translated into Polish from Karl Vossler's German version (Heidelberg 1908), see Dante ALIGHIERI, Boska Komedia. "Inferno", transl. Bernard Antochewicz (Wrocław: Wydawnictwo Gajt, 1993).

${ }^{121}$ For example: Volodymyr Wasylenko, Polskie losy Dantego w wieku XIX (Poznań: Poznańskie Towarzystwo Przyjaciół Nauk , 1993); Po Dantem. Wybór materiałów z VIII konferencji pracowników naukowych i studentów Inst. Nauk o Literaturze Polskiej U. Śl., ed. Józef Olejniczak (Katowice: Górnośląskie Centrum Kultury, 1996); Maria MAŚlANKA-Soro, Tragizm w Komedii Dantego (Kraków: Universitas, 2005); Richard W.B. LewIS, Dante, transl. Dorota Strukowska (Wrocław: ydawnictwo Dolnośląskie, 2004); Jacek GrZYBOwSKI, Miecz i pastorat. Filozoficzny uniwersalizm sporu o charakter wtadzy: Tomasz z Akwinu i Dante Alighieri (Kęty: Antyk, 2006); Jorge Luis Borges, Dziewięć esejów dantejskich (Nueve ensayos dantescos), transl. Joanna Partyka (Warszawa: Prószyński, 2007); etc.

${ }^{122}$ See the catalogues: Dante Jerzego Panka/Jerzy Panek's Dante, ed. J. Fejkiela (Kraków:, 2002); J. WoJcIechowski, Grzegorz Bednarski-Inferno/ Inferno/ Hell (Miasto: Polish Modern Art Foundation 2006); Dante in Polonia. Ottantaquattro scultori contemporanei interpretano Dante Alighieri (Ravenna: Centro dantesco dei frati minori conventuali, 1997). In the same "iconological” context we have Renata Bartnik's article, "Salvador Dalì i inni wokół 'Boskiej Komedii' Dantego", Akcent no. 3 (2005): 126-138.
} 
of the initial verses of Canto II of Paradise ("O voi che siete in piccioletta barca"). We must moreover mention aspects of the mass visibility of the names "dante" and "boska komedia," or the orchestra scores by Jan Kanty Pawluśkiewicz, the international theatre festival Boska Komedia [The Divine Comedy] in Krakow (divided into three parts: Inferno, Purgatory and Paradise) and the music album Triodante by the punk-rock group Armia (1994), adopted for a stage performance directed by Jarosław Orłowski. ${ }^{123}$ This register should no doubt be extended by references to Dante made in passing and by accident (which after Proust could be ascribed to "involuntary" literary memory), such as the rhyme "Dante/ quo ante" published in miniature in the weekly journal Polityka by the poet and theatre comedy group member, Jonasz Kofta (1942-1988), who simply wanted to say that reading The Divine Com$e d y$ is an experience which cannot leave the reader unchanged (quo ante). We could also add here the independent film by Malga Kubiak Gay Hell at Dante Cafè-The Defeat of the Vampires (2007), where Satan throws a party in a popular Warsaw gay venue "Le Madame" (later closed by the authorities), and the myth of Dante accompanied the musings, or rather the obsessions, of the director, related to her relations with her schizophrenic mother and father-poet (Tadeusz Kubiak), the freedom of creation and freedom in general, of the homosexual and queer stage in today's Poland.

The above enumeration, which by necessity does not allow an evaluation of all these novelties, influences and Dantean references in the contemporary Polish panorama, makes it possible to identify a definite shift from "an ethical Dante," related to the paradigm of Romanticism, to an "aesthetic Dante" of the postmodern turn (since, as we no longer believe, like Prince Myshkin from Dostoevsky's Idiot, that "beauty shall save the world", we may always admit that "aesthetics may be helpful in life" ${ }^{124}$ ). "The need for Dante" I referred to before is, at least for old Europe, a closed chapter (are we positive about it, though?). We must note, however, that even the seemingly less important and peripheral history of the Polish Dante, including the most recent one, makes us realize that our divine cyber-civilization cannot do without his oeuvre, his unsettled journey and its destination, "sì come rota ch'igualmente è mossa, roll' $\mathrm{d}$ onward, like a wheel in even motion" (Paradise XXXIII,

\footnotetext{
${ }^{123}$ See the DVD from the concert-performance, released by Metal Mind Productions (2004); the Dantesque album of the Polish group preceded by over a decade a similar idea, carried out in 2006 by the far more popular heavy metal group Sepultura: CD Dante XXI.

${ }^{124}$ Zbigniew Herbert, Potęga smaku, in: IDEM, Raport z oblężonego miasta i inne wiersze (Wrocław: Wydawnictwo Dolnośląskie, 1992), 93.
} 
144). We can safely say that our civilization will not cease to need Dante, like bread, even if we have conquered the sun and the other stars. 


\section{BIBLIOGRAPHY}

Alighieri, Dante. Biesiada (Convivio), edited by Magdalena Bartkowiak-Lerch. Kęty: Antyk, 2004. AlighIERI, Dante. Boska Komedia. Wrocław: Zakład Narodowy im. Ossolińskich, 1977.

AlighiERI, Dante. Monarchia, edited by Władysław Seńko. Kęty: Antyk, 2002.

ALIGHIERI, Dante. O języku pospolitym (De vulgari eloquentia), edited by Włodzimierz Olszaniec. Kęty: Antyk, 2002.

Alighieri, Dante. Pieśniarz, edited by Juliusz Feldhorn. Kraków-Roma: Sztuka-KsiążkaWydawnictwo, 1926.

Auerbach, Erich. Studi su Dante [Studies on Dante]. Milano: Feltrinelli, 1983.

BARBI, Michele. Dante. Vita, opere e fortuna. Firenze: G.C. Sansoni, 1933(!).

BARTNIK, Renata. “Salvador Dalì i inni wokół ‘Boskiej Komedii’ Dantego.” Akcent No. 3 (2005): $126-138$.

BEŁZA, Igor. "Niektóre rysy polskiego romantyzmu. Inspiracje dantejskie." Studia Filozoficzne No. 7(107) (1974): 83-92.

BetheA, David M. Joseph Brodsky and the Creation of Exile. Princeton, N.J.: Princeton University Press, 1994.

Bloom, Harold. The Western Canon: The Books and School of the Ages. New York: Harcourt Brace \& Company, 1994.

Borges, Jorge Luis. Dziewięć esejów dantejskich (Nueve ensayos dantescos). Translated Joanna Partyka. Warszawa: Prószyński, 2007.

Brodski, Josif. W cieniu Dantego. Translated by Krystyna Tarnowska and Andrzej Konarek. In IDEM. "Śpiew wahadła.” Zeszyty Literackie 55 (1999): 63-73.

BrodskiJ, Iosif. "Lettera al lettore italiano." Translated G. Forti. In Zbigniew Herbert. Rapporto dalla città assediata, edited by Pietro Marchesani, 11-21. Milano: Adelphi, 1993.

BrodskiJ, Iosif. Fondamenta degli incurabili. Milano: Adelphi, $2004^{12}$.

BrodskiJ, Iosif. Profilo di Clio, edited by Arturo Cattaneo, 41-56. Milano: Adelphi, 2003.

Brzozowski, Stanisław. "Sztuka i społeczeństwo (1903).” In IDEM. Eseje i studia o literaturze, edited by Henryk Markiewicz, B.N. series I no. 258, v. I, 109. Wrocław: Zakład Narodowy im. Ossolińskich, 1990.

Cataluccio, Francesco M. Niedojrzatość. Choroba naszych czasów. Kraków: Znak, 2006.

Cavanagh, Clare. "Poetyka żydowskości: Mandelsztam, Dante a 'zaszczytne powołanie Żyda'.” Teksty Drugie No. 5 (1992): 47-62.

Cavanagh, Clare. "Zametki k Razgovoru o Dante O. Mandel'štama." International Journal of Slavic Linguistics and Poetics No. 15 (1972): 184-197.

CeCcherelli, Andrea. "Miłosz e Dante." In Italia Polonia Europa. Scritti in memoria di Andrzej Litwornia, edited by Andrea Ceccherelli et al., 98-113. Roma: Accademia Polacca delle Scienze, 2007.

CiCCARINI, Marina. Żart, inność, zbawienie. Studia z literatury i kultury polskiej. Warszawa: Neriton, 2008.

Cimino, Nelly. “L’influenza di Dante nell'Anhelli.” Rivista di cultura No. 3 (1926): 66-70. 
Colucci, Michele. Tra Dante e Majakovskij. Saggi di letterature comparate slavo-romanze, edited by Rita Giuliani. Rome: Carocci, 2007.

CURTIUS, Ernst Robert. Literatura europejska i łacińskie średniowiecze, edited by Andrzej Borowski. Kraków: Universitas, $1997^{2}$.

Czapliński, Przemysław. Polska do wymiany. Późna nowoczesność i nasze wielkie narracje. Warszawa: Wydawnictwo W.A.B, 2009.

Czestawa Miłosza autoportret przekorny. Rozmowy przeprowadzit Aleksander Fiut. Kraków: Wydawnictwo Literackie, 1994.

Dante in Polonia. Ottantaquattro scultori contemporanei interpretano Dante Alighieri. Ravenna: Centro dantesco dei frati minori conventuali, 1997.

Dante Jerzego Panka/Jerzy Panek's Dante, edited by Jan Fejkiel. Kraków: Jan Fejkiel Gallery, 2002.

De Carlo, Andrea Fernando. Dante nella Polonia del XIX secolo. Le traduzioni della Divina Commedia a confronto: Kraszewski, Korsak, Stanistawski, Porębowicz. Tesi di dottorato in Scienze letterarie, filologiche, linguistiche e glottodidattiche. Università del Salento, Lecce, 2008/2009, 37 [doctoral dissertation, typescript].

DE Rooy, Ronald. "Il poeta che parla ai poeti". Elementi danteschi nella poesia italiana ed anglosassone del secondo Novecento. Firenze: Cesati, 2003.

Even-Zohar, Itamar. "The Position of Translated Literature within the Literary Polysystem." Papers on Poetics and Semiotics No. 8 (1978): 21-27.

FloRYŃSKA, Halina. Wincenty Lutosławski-metafizyka jaźni i narodu. In Polska myśl filozoficzna i społeczna, v. III, edited by Barbara Skarga. Warszawa: Książka i Wiedza, 1977.

GAŁCZYŃSKI, Konstanty Ildefons. Dzieła w pięciu tomach, v. II: Poezje. Warszawa: Czytelnik, 1979.

GaŁCZYŃSKI, Konstanty Ildefons. Miłość (1947). In IDEM. Dzieła, v. III: Próby teatralne, edited by Kira Gałczyńska, Barbara Kowalska, 470. Warszawa: Czytelnik, 1979.

GAŁCZYŃSKI, Konstanty Ildefons. Notatnik spisany w dniach 18 sierpnia-18 listopada $1941 \mathrm{r}$. w Altengrabow. Warszawa: Bellona, 2009.

GiUliani, Rita. "Quando la Russia parla europeo." Critica del testo X/1 (2007), monograph issue: Il canone europeo: $165-176$.

Gombrowicz, Witold. Dziennik (1953-1958). Paryż: Gallimard, 1982².

Gombrowicz, Witold. Ferdydurke, edited by Jan Błoński. Kraków: Wydawnictwo Literackie, 1986.

GrUdZIŃsKA-Gross, Irena. Miłosz i Brodski-pole magnetyczne. Introduction Tomas Venclova. Kraków: Znak, 2007.

GRZYBowski, Jacek. Miecz i pastorat. Filozoficzny uniwersalizm sporu o charakter władzy: Tomasz z Akwinu i Dante Alighieri. Kęty: Antyk, 2006.

Herbert, Zbigniew. Potęga smaku. In IDEM. Raport z oblężonego miasta i inne wiersze, 93. Wrocław: Wydawnictwo Dolnośląskie, 1992.

JACCOTTET, Philippe. La parola Russia, edited by Antonella Anedda. Roma: Donzelli, 2004.

JANION, Maria. "Zmierzch paradygmatu" [The Decline of the Paradigm]. In EADEM. Do Europy tak, ale razem z naszymi umartymi, 19-34. Warszawa: Sic!, 2000.

KARPIŃSKI, Wojciech. Pamięć Wtoch. Warszawa: Fundacja Zeszytów Literackich, $2008^{3}$.

KuCIAK, Agnieszka. Dante romantyków: recepcja Boskiej Komedii u Mickiewicza, Stowackiego, Krasińskiego i Norwida. Poznań: Wydawnictwo Naukowe UAM, 2003. 
LagercrantZ, Olof. Od piekieł do raju. Dante i Boska Komedia. Warszawa: Państwowy Instytut Wydawniczy, 1970.

ŁAPIŃSKI, Zdzisław. Ja, Ferdydurke. Gombrowicza świat interakcji. Lublin: Redakcja Wydawnictw KUL, 1985.

LELEWEL, Joachim. Geographie du Moyen Age. Bruxelles: Pilliet, 1852-1857.

ŁEMPICKI, Stanisław. "Miłość dantejska w poemacie 'W Szwajcarii'.” Pamiętnik Literacki No. 1 (1924/25): 155-182.

Levi, Primo. Se questo è un uomo (Czy to jest cztowiek), 138-145. Torino: Einaudi, 1968.

LewIS, Richard W.B. Dante. Translated Dorota Strukowska. Wrocław: Wydawnictwo Dolnośląskie, 2004.

LitworniA, Andrzej. "Dante, któż się odważy ttumaczyć.” Studia o recepcji Dantego w Polsce. Warszawa: Zakład Narodowy im. Ossolińskich, 2005.

Łotman, Mikhail. "Poet i smert' (iz zametok o poetike Brodskogo)." In Blokovskij sbornik XIV, edited by Lea Pild and Galina Ponomareva, 188. Tartu: Tartu Ülikooli Kirjastus, 1998.

ŁukASzuK-Piekara, Małgorzata. "Wizje splatane z historiami”. Autobiografia liryczna poety. Lublin: Wydawnictwo KUL, 2000.

MACIEJEWSKI, Jarosław. Florenckie poematy Słowackiego. Wrocław: Zakład Narodowy im. Ossolińskich, 1974.

MAndel'štam, Osip. "Vokrug 'Razgovora o Dante'." In IDEM. Sobranie sočinenij v četyrech tomach, edited by Ėmilija Sergeev, vol. 3: Stichi i proza 1930-1937. Moskva: ART-BiznesCentr, 1994.

MANDEL'ŠTAM, Osip. Razgovor o Dante (1932).

MARCheSANI, Pietro. "Per una rilettura della 'Non Divina Commedia' di Zygmunt Krasiński, poeta romantico polacco." In Dantismo Russo e cornice europea. Atti del Convegno di AlgheroGressoney (1987). Introduction Eridano Bazzarelli, v. 1, 47-53. Firenze: Olschki, 1989.

MarinElli, Luigi. “Tam jest mój dom’. Wokół dantyzmu Miłosza.” An unpublished paper delivered at an international conference Miłosz i Miłosz. Kraków: Wydawnictwo UJ, May 2011

MARINELLI, Luigi. "Kanony i kanonady. O kanonie 'europejskim' a literaturach 'mniejszych' (na przykładzie literatury polskiej)." In: Europejski kanon literacki. Dylematy XXI wieku, edited by Elżbieta Wichrowska, 90-106. Warszawa: Wydawnictwo UW, 2012.

MARINELLI, Luigi. "Le témoignage et la compassion: les attitude du sujet lyrique dans l'oeuvre de Czesław Miłosz, Zbigniew Herbert et Wisława Szymborska.” In Le témoignage dans la littérature polonaise du XX $X^{e}$ siècle, edited by Hanna Konicka et Charles Zaremba, 193-195. Paris: Institut d'études slaves, 2008.

Marinelli, Luigi. Tra Oriente europeo e Occidente Slavo. Russia e Polonia. Roma: Lithos, 2008.

Maślanka-Soro, Maria. Tragizm w Komedii Dantego. Kraków: Universitas, 2005.

Meriggi, Bruna. “Motywy dantejskie w 'Królu Duchu' Słowackiego.” In Mélanges de littérature comparée et de philologie offerts à Mieczystaw Brahmer, 349-356. Warszawa: Państwowe Wydawnictwo Naukowe, 1967.

MickIEwICZ, Adam. Literatura stowiańska. Kurs drugi (lecture XXIII). Translated by Leon Płoszewski. In IDEM. Dzieta, v. X. Warszawa: Czytelnik, 1955.

MikoŁaJewsKi, Jarosław. Tradurre Dante in polacco. Udine: Forum, 2004. 
MıŁosz, Czesław. Dante (in the series Dalsze Okolice, 1991). Reprint in IDEM. Wiersze, v. 4, 284. Kraków: Znak, 2004.

MıŁosz, Czesław. Nobel Lecture, bilingual edition. New York: Farrar Straus Giroux, 1980.

MıŁosz, Czesław. Prywatne obowiazki. Paryż: Instytut Literacki, 1980².

MıŁosz, Czesław. Przygody młodego umystu. Kraków: Znak, 2003.

MıŁosz, Czesław. Rok myśliwego. Paryż: Instytut Literacki, 1990.

MıŁosz, Czesław. Świadectwo poezji. Sześć wykładów o dotkliwościach naszego wieku. Paryż: Instytut Literacki, 1983.

MıŁosz, Czesław. The Separate Notebooks: Poems, edited by Robert Pinsky with Renata Gorczynski and Robert Hass. New York: Ecco, 1984.

MıŁosz, Czesław. Wiersze ostatnie. Kraków: Znak, 2006.

Morawski, Kalikst. Dante Alighieri. Warszawa: Wydawnictwo Pax, 1961.

OwCZARSKI, Wojciech. Miejsca wspólne, miejsca własne. O wyobraźni Leśmiana, Schulza i Kantora. Gdańsk: Słowo/obraz terytoria, 2006.

PARNICKI, Teodor. Tylko Beatrycze [Only Beatrice]. Warszawa: Wydawnictwo Pax, 1962.

Pasolini, Pier P. Bluźnierstwo. Wybór poezji, edited by Jarosław Mikołajewski. Warszawa: Wydawnictwo Teta Veleta, 1999.

PINSKY, Robert. The Inferno of Dante: A New Verse Translation, with notes by Nicole Pinsky and foreword by John Freccero. New York: Noonday Pr, 1996.

PŁaszewsKa, Olga. Przestrzenie komparatystyki-italianizm. Kraków: Wydawnictwo UJ, 2010.

Po Dantem. Wybór materiałów z VIII konferencji pracowników naukowych i studentów Inst. Nauk o Literaturze Polskiej U. Śl., edited by Józef Olejniczak. Katowice: Górnośląskie Centrum Kultury, 1996.

PoluchinA, Valentina. "Pleasing the Shadows. Brodsky's Debt to Puškin and Dante." In Firenze e San Pietroburgo. Due culture si confrontano e dialogano tra loro, collected edition by Alberto Alberti and Stefania Pavan, 176-206. Firenze: Università degli studi di Firenze, 2003.

PreISNER, Walerian. Dante i jego dzieła w Polsce. Bibliografia krytyczna z historycznym wstępem. Toruń: Państwowe Wydawnictwo Naukowe, 1957.

RABIzo-BIREK, Magdalena. "Szlakiem Dantego i Schulza.” Kresy. Kwartalnik Literacki 63 (2005): 77-91.

RozPĘDOwska, M. Dante w Polsce (1957-1981) (Warszawa: 1983).

SALWA, Piotr. "Dante e la critica polacca degli ultimi anni." In Dante i slavenski svijet, edited by Frano Čale, v. II, 589-596. Zagreb : Jugoslavenska Akademija Znanosti i Umjetnosti, 1984.

Salwa, Piotr. "Dante in Polonia: una presenza viva?" Dante Studies CXIX (2001): 187-202.

Schulz, Bruno. Kometa. In IDEM. Proza. Kraków: Wydawnictwo Literackie, 1973.

Segre, Cesare. "Se questo è un uomo di Primo Levi." In Letteratura italiana, edited by Alberto Asor Rosa, Le opere, v. IV.2, 491-508. Torino: Einaudi, 1996.

Sergl, Anton. "Mąż. Koncepcja płci w Nie-Boskiej Komedii Zygmunta Krasińskiego.” In Ciało-Pteć-Literatura. Prace ofiarowane profesorowi Germanowi Ritzowi, edited by Magdalena Hornung et al., 69-104. Warszawa: Wiedza Powszechna, 2001.

SHEFFY, Rakefet. "The Concept of Canonicity in Polisystem Theory.” Poetics Today 11 (1990): $511-522$. 
SKWARCZYŃSKA, Stefania. Pomiędzy historia a teoria literatury. Warszawa: Pax, 1975.

ŚLASKI, Jan. "Iosif Brodskij e la sua finestra polacca sul mondo.” In Nei territori della slavistica. Percorsi e intersezioni. Scritti per Danilo Cavaion, edited by Cinzia De Lotto, Adalgisa Mingati, 376-386. Padova: Unipress, 2006.

SMith, Stan. "Proper Frontiers: Transgression and Individual Talent." In T.S. Eliot and the Concept of Tradition, collected edition, edited by Giovanni Cianci and Jason Harding, 22-40. Cambridge: Cambridge University Press, 2007.

SpeELman, Raniero. "Ebrei italiani nel rifugio svizzero: asilo ameno o purgatorio?" In Tra storia e immaginazione: gli scrittori ebrei di lingua italiana si racconatano, edited by Hanna Serkowska, 43-58. Kraków: RABID, 2008.

STRoŃSKI, Stanisław. "Wpływ Dantego w 'Grobie Agamemnona'.” Pamiętnik Literacki (1909): $152-157$.

SvIRIDA, Inessa I. "Igor Fedorovič Bel'za kak istorik kul'tury." In Dantovskie čtenija/ Letture dantesche 1995, edited by Aleksandr IIjušin, 12-18. Moskva: Nauka, 1996.

Szajna, Józef. "Teatr organiczny.” In Świadomość teatru. Polska myśl teatralna drugiej połowy XX wieku, edited by Wojciech Dudzik, 74-75. Warszawa: Wydawnictwo Naukowe PWN, 2007.

SZILÀRD, Lena, Peter BARTA. "Dantov kod russkogo simvolizma." In Parallelismi e rapporti tra il Trecento italiano nonchè la lingue e le culture romanze e slave. Materiali del Simposio internazionale, monograph issue Studia Slavica Academiae Scientiarium Hungaricae XXXV, No. 1-2, (1989): 61-95.

SzymaK-ReIFERova, Jadwiga. “Zof'ia.” In Kak rabotaet stichotvorenie Brodskogo, edited collection, edited by Lev Losev, Valentina Poluchina, 10-32. Moskva: Novoe Literaturnoe Obozrenie, 2002.

Szymborska, Wisława. Poezje. Warszawa: Alfa, $1987^{3}$.

ThOMPSOn, Ewa. Trubadurzy Imperium. Literatura rosyjska i kolonializm. Kraków: Universitas, 2000.

TuwIM, Julian. Komedia boska. In IDEM. Rzecz czarnoleska (1929), Dzieła, edited by Juliusz W. Gomulicki, Jarosław Iwaszkiewicz, Mieczysław Jastrun, Antoni Słonimski, v. II.2, 17. Warszawa: Czytelnik, 1955.

Ungaretti, Giuseppe. "Lettre à Dominique de Roux.” Cahier de l'Herne No. 14 (1971).

VincenZ, Stanisław. Atlantyda. Pisma rozproszone z lat II wojny światowej, edited by Jerzy Snopek. Warszawa: Świat Literacki, 1994.

VinCEnZ, Stanisław. Czym może być dziś dla nas Dante. In IDEM. Eseje i szkice zebrane, selected and edited by Andrzej Wincenz, vol. 1, 197-229. Wrocław: Wirydarz, 1997.

VincenZ, Stanisław. Po stronie pamięci. Wybór esejów. Paryż: Instytut Literacki, 1965.

Wasylenko, Volodymyr. Polskie losy Dantego w wieku XIX. Poznań: Poznańskie Towarzystwo Przyjaciół Nauk, 1993.

WAT, Aleksander. Publicystyka, edited by Piotr Pietrych. Warszawa: Czytelnik, 2008.

Wilczek, Piotr. "Kanon tradycji uniwersalnej a zadania narodowej historii literatury." In Polonistyka w przebudowie. Zjazd Polonistów Kraków 22-25 września 2004, edited by Małgorzata Czermińska et al., v. II, 111-120. Kraków: Universitas, 2005.

WindakIEwICZ, Stanisław. Badania źródłowe nad twórczościa Słowackiego. Kraków: [s.n.], 1910.

Wojciechowski, Jerzy. Grzegorz Bednarski-Inferno/ Inferno/ Hell. Miasto: Polish Modern Art Foundation 2006. 
WyноwSKA, Wanda De Andreis. "Dante nell'opera di Giulio Słowacki." Rivista di Letterature Slave No. 5 (1932): 342-374.

ŻAвоKLICKI, Krzysztof. Da Dante a Pirandello. Saggi sulle relazioni letterarie italo-polacche. Warszawa-Rzym: Accademia Polacca delle Scienze, Biblioteca e Centro di Studi a Roma, 1994.

\section{POLISH DANTISM: BETWEEN THE EPIC AND ETHICS}

\section{Summary}

This essay proposes a synthesis of the major themes and issues of Polish Dantism, with a particular reference to the 20th century and beyond. The author retraces the traditional motifs which connect $20^{\text {th }}$-century authors to the Romantic tradition, and discusses some examples (Gombrowicz, Vincenz, Miłosz) in a broader comparative context (referring specifically to Eliot, Mandelstam, Brodsky). The author argues that the Modernist ethical idea of "necessary Dante" tends to be gradually replaced by a Postmodernist notion of "aesthetic Dante," with a flowering of new translations - not only of the Divina Commedia. These works restore a balance between Polish literary Dantism and Dante studies. In this sense, the Polish situation displays a lot of similarity to the European and international context, abundant with trends and concerns which go far beyond those of a national language and literature.

Key words: Dante/Dantism, Dante studies, tradition, Polish literature, comparative literature.

Translated by Marcin Turski

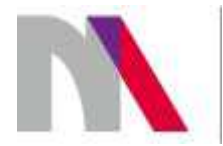

The preparation of the English version of Roczniki Humanistyczne (Annals of Arts) and its publication in electronic databases was financed under contract no. 836/P-DUN/2018 from the resources of the Minister of Science and Higher Education for the popularization of science. 